\title{
WIASTER
}

Y-2161

\section{THERMOPHYSICAL PROPERTIES OF CONASAUGA SHALE}

D. D. Smith

\section{OAK RIDGE Y-12 PLANT} OAK RIDGE. TENNESSEE

prepared for the U.S. DEPARTMENT OF ENERGY under

U.S. GOVERNMENT Contract W-7405 eng 26 


\section{DISCLAIMER}

This report was prepared as an account of work sponsored by an agency of the United States Government. Neither the United States Government nor any agency Thereof, nor any of their employees, makes any warranty, express or implied, or assumes any legal liability or responsibility for the accuracy, completeness, or usefulness of any information, apparatus, product, or process disclosed, or represents that its use would not infringe privately owned rights. Reference herein to any specific commercial product, process, or service by trade name, trademark, manufacturer, or otherwise does not necessarily constitute or imply its endorsement, recommendation, or favoring by the United States Government or any agency thereof. The views and opinions of authors expressed herein do not necessarily state or reflect those of the United States Government or any agency thereof. 


\section{DISCLAIMER}

Portions of this document may be illegible in electronic image products. Images are produced from the best available original document. 
Reference to a company or product name does not imply approval or recommendation of the product by Union Carbide Corporation or the Department of Energy to the exclusion of others that may meet specifications.

Printed in the United States of America. Available from National Technical Information Service

U.S. Department of Commerce

5285 Port Royal Road, Springfield, Virginia 22161

Price: Printed Copy $\$ 4.50 ;$ Microfiche $\$ 3.00$

This report was prepared as an account of work sponsored by an agency of the United States Government. Neither the United States Government nor any agency thereof, nor any of their employees, nor any of their contractors, subcontractors, or their employees, makes any warranty, express or implied, nor assumes any legal liability or responsibility for any third party's use or the results of such use of any information. apparatus, product or process disclosed in this report, nor represents that its use by such third party would not infringe privately owned rights. 
Date of Issue: December 4, 1978

Distribution Category: UC-70

\title{
THERMOPHYSICAL PROPERTIES OF CONASAUGA SHALE
}

\author{
D. D. Smith
}

Instrumentation and Characterization Department

Y-12 Development Division

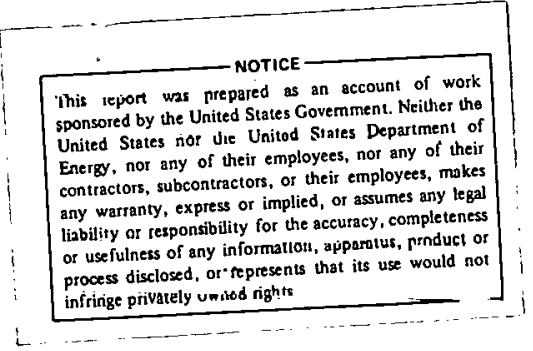

Oak Ridge Y-12 Plant

P. O. Box Y, Oak Ridge, Tennessee 37830

Prepared for the Department of Energy Under US Government Contract W-7405-eng-26 


\begin{abstract}
Thermophysical-property characterizations of five Conasauga shale cores were determined at temperatures between 298 and $673 \mathrm{~K}$. Methods of specimen fabrication for different tests were evaluated. Thermal-conductivity and thermal-expansion data were found to be dependent on the structure and orientation of the individual specimens. Thermal conductivities ranged between 2.8 and $1.0 \mathrm{~W} / \mathrm{m}-\mathrm{K}$ with a small negative temperature dependence. Thermal expansions were between 2 and $5 \times 10^{-3}$ over the temperature range for the group. Heat capacity varied with the composition.
\end{abstract}




\section{CONTENTS}

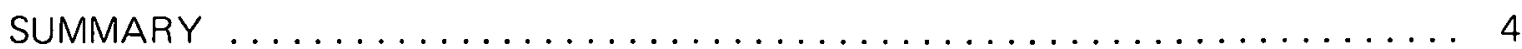

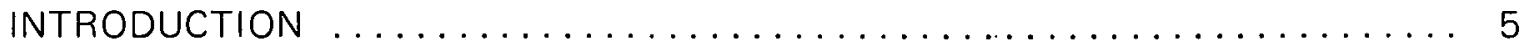

THERMOPHYSICAL PROPERTIES OF CONASAUGA SHALE $\ldots \ldots \ldots \ldots \ldots \ldots \ldots$

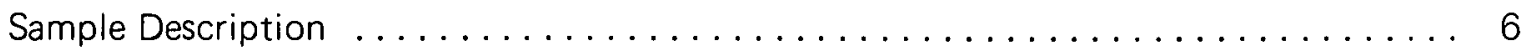

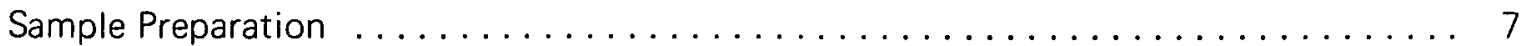

Physical Properties ............................... 8

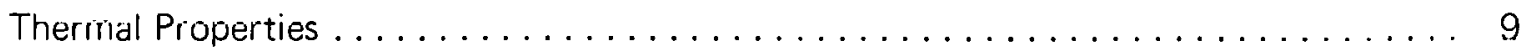

Thermal-Behavior Tests $\ldots \ldots \ldots \ldots \ldots \ldots \ldots \ldots \ldots \ldots \ldots \ldots$

Heat-Capacity Measurements . . . . . . . . . . . . . . . . 10

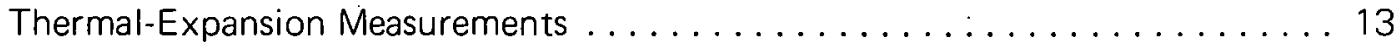

Thermal-Conductivity Measurements . . . . . . . . . . . . . . . . . . . . . 17

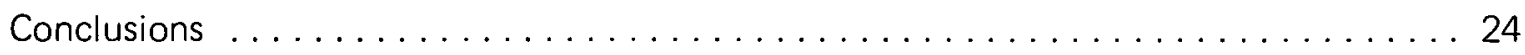

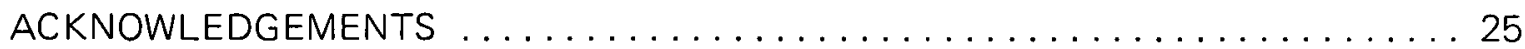

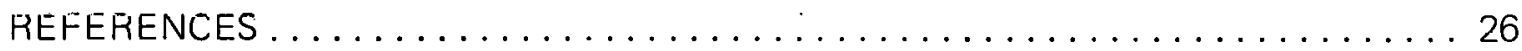




\section{SUMMARY}

Thermophysical-property measurements were conducted on five shale cores representative of eastern illitic shale found under the Oak Ridge reservation. (a) Cores were converted to thermal-conductivity and expansion test specimens using low-speed diamond cutting techniques (dry). Standard machining techniques were found not to be useable due to spalling.

Thermal conductivities measured by two comparative techniques were between 2.8 and 1.0 $\mathrm{W} / \mathrm{m}-\mathrm{K}$ over a temperature range from 328 to $673 \mathrm{~K}$ with heat flow 30 to 40 degrees relative to the bedding plane. Thermal conductivity decreased from $1-8 \%$ when measurements were repeated on the same specimen. A comparative point-probe instrument was used as a part of thermal conductivity screening technique. Thermal expansions for the group varied between 0.2 and $0.5 \%$ at $673 \mathrm{~K}$. No correlation between core orientation and thermal expansion could be made although significant differences were observed among the specimens. Heat capacities ranged smoothly from $0.21 \mathrm{cal} / \mathrm{g}-\mathrm{K}$ at $293 \mathrm{~K}$ to $0.28 \mathrm{cal} / \mathrm{g}-\mathrm{K}$ at $673 \mathrm{~K}$ for the three dark-gray shale cores. Other cores exhibited lower heat capacities because of compositional differences.

(a) Federally owned land, in Anderson and Roane counties of Tennessee, which contain three facilities operated by Union Carbide Corporation's Nuclear Division for the Department of Energy. 


\section{INTRODUCTION}

The objectives of this study, conducted at the Oak Ridge $\mathrm{Y}-12$ Plant $(\mathrm{b})$, were to adequately define the thermophysical properties of these shale cores at temperatures up to $673 \mathrm{~K}$, to develop cost-effective methods of fabrication applicable to these types of tests for large numbers of specimens, and to evaluate thermal-conductivity test methods and procedures for these and similar geologic materials for the Office of Waste Isolation (OWI).

Terminal repositories for the long-term storage of radioactive reactor wastes have been proposed to be located within geologic media such as shale or salt for safety and containment purposes. Knowledge of the thermal behavior of shale is needed as heat from the radioactive wastes will ultimately be dissipated to the surrounding geologic formations. Thermal-conductivity and diffusivity characteristics of the geologic media are necessary for accurate mathematical modeling of repositories. Long-term elevated temperatures may significantly alter the mechanical and heat-transfer characteristics of the shale, thus changing the temperatures and heat distributions from the stored array. Property tests were limited to an upper temperature of $673 \mathrm{~K}$, which is well above the probable maximum temperature in an array. At approximately $875 \mathrm{~K}$, the composition and properties of the shale changes significantly because of the evolution of chemically bound water from the constituent clay minerals.

(b) One of the three Oak Ridge facilities that are operated by the Union Carbide Corporation's Nuclear Division for the Department of Energy. 


\section{THERMOPHYSICAL PROPERTIES OF CONASAUGA SHALE}

\section{SAMPLE DESCRIPTION}

Conasauga shale, an anisotropic, sedimentary rock of variable structure and composition found bedded under the Oak Ridge reservation, consists primarily of micas, kaolinite, and feldspar, and other minerals in lesser quantities. It was selected by the Office of Waste Isolation (OWI) as representative of the eastern illitic shales. Formation is from the consolidation of sedimentary silt, clay, and mud. ${ }^{1}$

The five selected cores submitted by the OWI were chosen to be characteristic of the range of material types which could be expected from the Oak Ridge site. The samples originated from the OWI's In Situ Conasauga Experiment, 1976. The core sections, $50 \mathrm{~mm}$ in diameter and between 150 and $300 \mathrm{~mm}$ in length, are identified by bore hole number and depth of origin (in feet). They are 15-34, 8-92, 8-99, 18-119, and 13-88. The cores were bored while using water for debris removal. Thus, they were partially saturated with water for a short period of time. Views of these five core sections are presented in Figures 1 - 5. All were observed to be of contiguous material, showing distinct layers with fissures, striations, and small-scale shearing, indicative of the orientation of the bedding plane. Variations in color and texture were quite evident. Colors varied from light to mottled gray (Cores 15-34 and

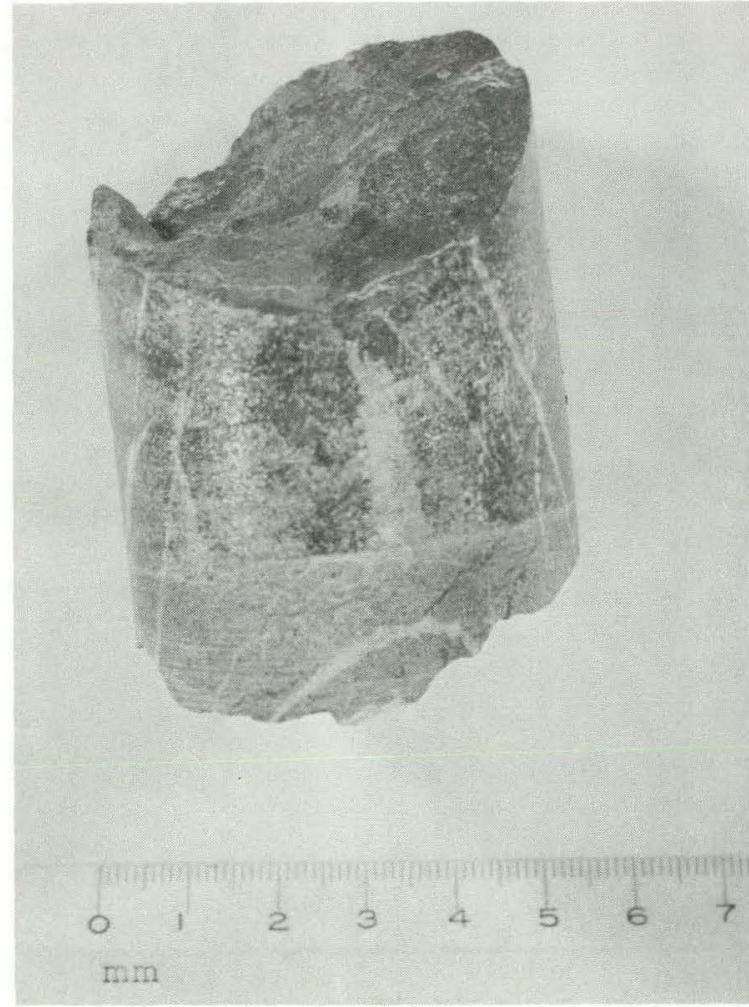

Figure 1. CORE 15-34, PRIMARILY LIMESTONE. (Light Areas are Shale)

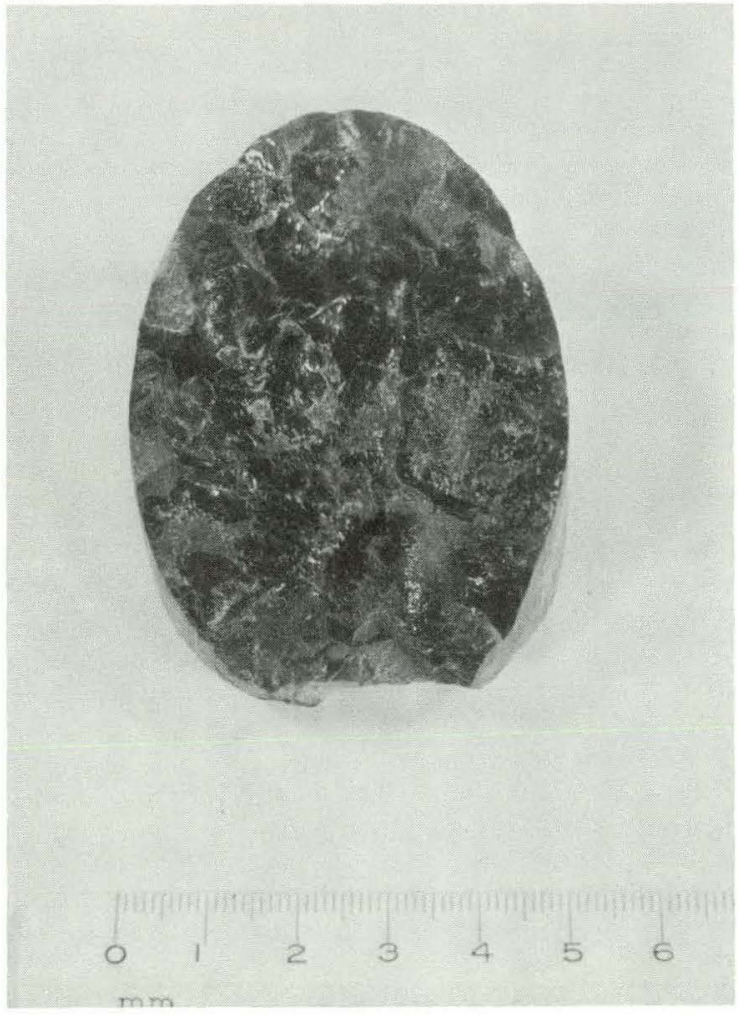

Figure 2. CORE 8-92, SHOWING GLASSY FRACTURED SURFACES. (Also Representative of Cores 8-99 and 18-119) 


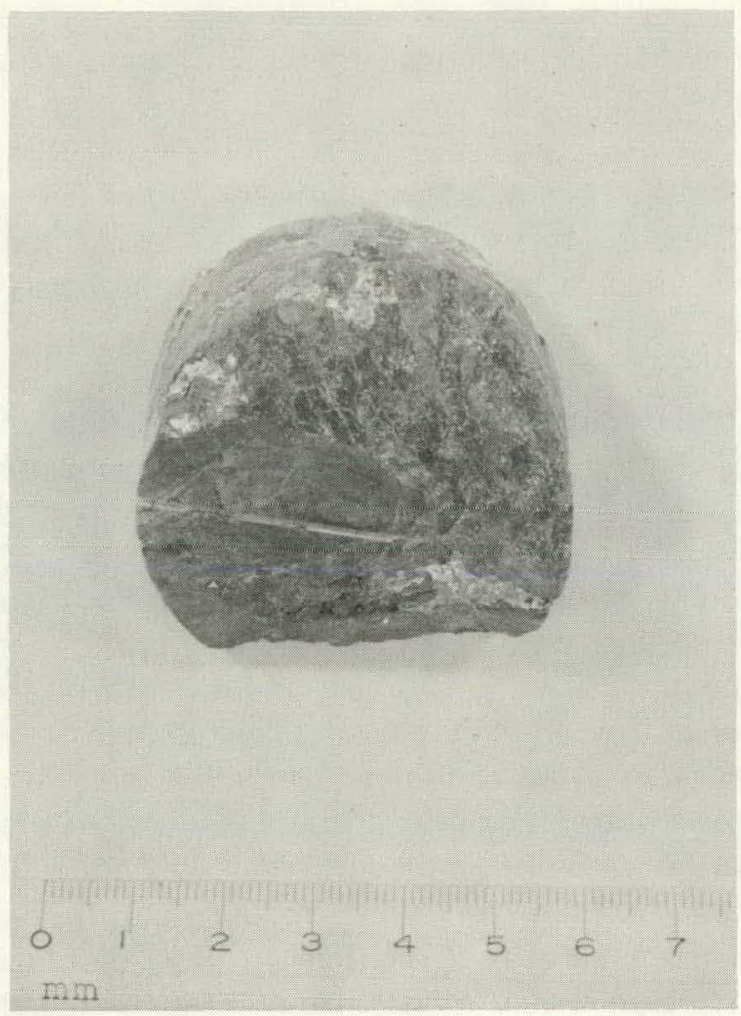

Figure 3. CORE 13-88, SHOWING SPALLING OF THE MILLED SURFACE. (Slot is for Thermocouple Placement)

13-88) to medium dark gray (Cores 8-92, 8-99, and 18-119). The latter three cores are characteristic shale which were quite friable and could be separated and chipped with only thumb-nail pressure. Core 13-88 was the most casily broken whereas Core 15-34 was misch harder than the rest of the group. Core 13-88 also exhibited the least amount of visible texturing. The three calcareous shales (Cores 8-92, 8-99, and 18-119) exhibited shiny, glass-like overtones at the fractured surfaces.

\section{SAMPLE PREPARATION}

One objective of the study was to assess the cost effectiveness of methods of fabricating property test specimens from the cores. The cores were extremely friable (one core broke when laid on a table) and consisted of localized hard and soft areas. Difficulties in machining the test specimens were expected because of these inhomogeneities and varia-

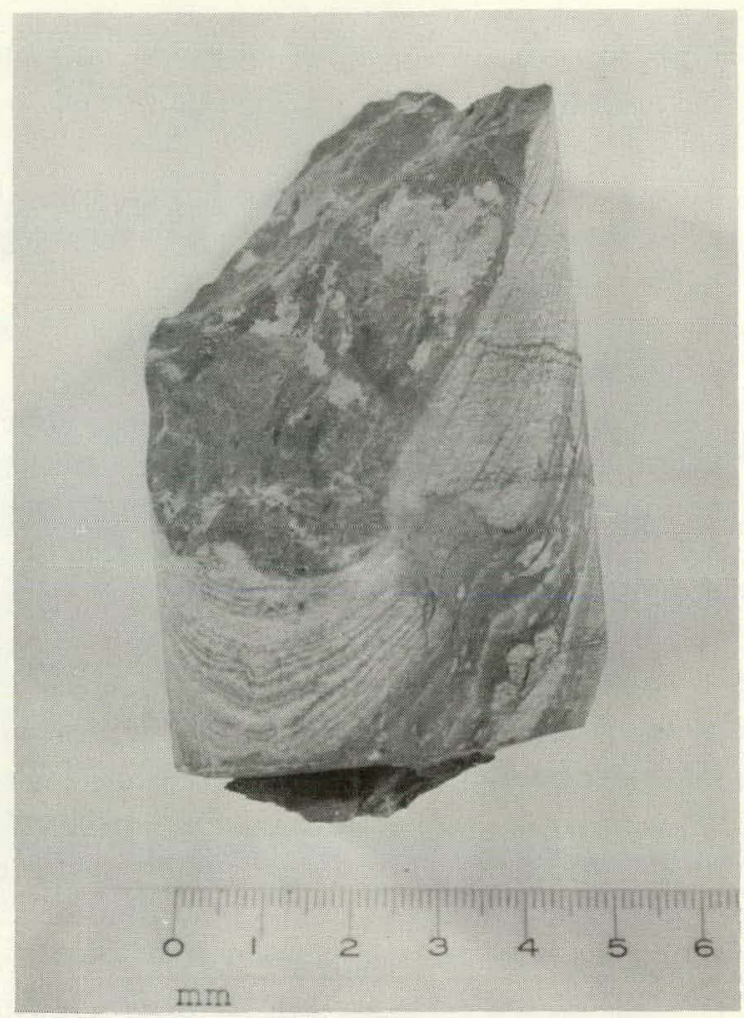

Figure 4. CORE 13-88, SHOWING VARIABILITY OF COMPOSITION. (Light Bands of Quartz are Indicative of the Bedding Plane)

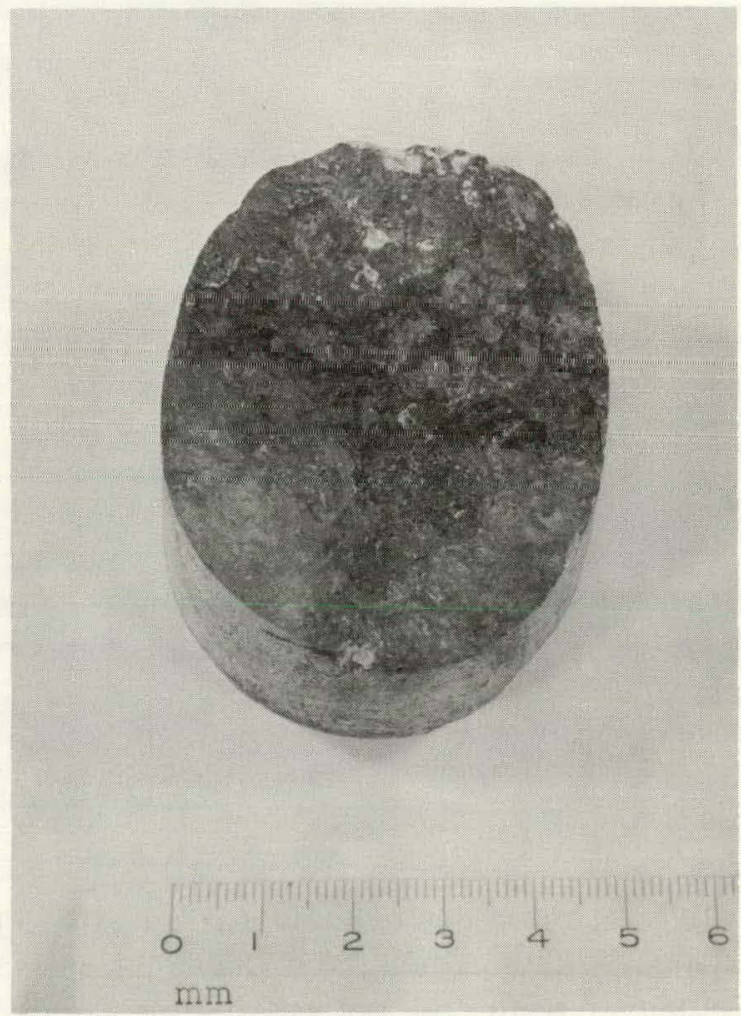

Figure 5. CORE 15-34, SHOWING VARIABILITY OF TEXTURE AND COLOR. 
tions in composition. Consequently, test-specimen fabrication constituted a substantial part of the total cost in the testing operations.

The cores (as received) were stored in sealed plastic bags in a low-relative-humidity room prior to the fabrication and property tests. Because the shale was porous, fabrication techniques were limited to those that did not involve liquids or oils since unnecessary contamination would render the materials useless for property measurements.

Thermal-conductivity specimens are right circular cylinders approximately $51 \mathrm{~mm}$ in diameter by $16 \mathrm{~mm}$ thick, with smooth, parallel faces. Thermal-expansion specimens are nominally $6 \mathrm{~mm}$ cross sections $25 \mathrm{~mm}$ long.

Machining the cores to form the thermal-conductivity specimens without shattering them required a protective sheath to absorb shock when they were held in a lathe chuck. A girdle of Cerrobend, a low-melting-point $(330 \mathrm{~K})$ metallurgical alloy, was cast around the core to provide a uniform and stable mounting collar for milling the flat surfaces of the thermal-conductivity specimens. First, the cores were sliced to their rough dimensions with a bandsaw. A small carbide mill was used to remove unwanted material from the faces of the specimens. Since considerable spalling was observed with this procedure, it was abandoned. Figure 3 shows the spalling encountered on Core 13-88. A high-speed masonry cutoff saw and a diamond-impregnated cutoff wheel were also investigated. Neither of these methods was satisfactory for cutting the cores because the relatively high cutting speeds induced enough vibration in the materials to cause them to spall and shatter. A low-speed, serrated diamond saw mounted on a lathe bed gave reasonably good surfaces without too much spalling or surface damage. The surfaces were subsequently lapped and polished by hand, using progressively finer grades (to 400 grit) of abrasive paper. This cutting technique was also found to be adequate for slicing thermal-expansion specimens.

Linear-thermal-expansion specimens were fabricated in directions hnth transverse and lonyiludinal to the bored core axes. The specimens, nominally $25 \mathrm{~mm}$ in length by $6 \mathrm{mrn}$ in cross-sectional diameter, were cut from the cores by using the low-speed diamond saw. The specimen ends were ground flat and parallel by using a diamond cutoff wheel. Several specimens shattered during the fabrication process. Each thermal-expansion or conductivity specimen can be fabricated in two hours.

\section{PHYSICAL PROPERTIES}

Standard mercury-intrusion-porosimeter techniques were used to obtain density, porosity, surface-area, and average-pore-diameter values on both as-received material and material that was heated to $673 \mathrm{~K}$ and held at this temperature for one hour.

Bulk-density measurements were also made on the thermal-conductivity specimens prior to testing. Orientation of each core relative to the bedding plane was determined by using a protractor.

Physical properties of the cores are listed in Table 1. Bulk densities by porosimeter showed little variation among the unheated specimens $\left(2.68\right.$ to $\left.2.72 \mathrm{~g} / \mathrm{cm}^{3}\right)$, although densities obtained from the pretest thermal-conductivity specimens were smaller and had larger 
Table 1

PHYSICAL PROPERTIES OF THE SHALE CORES

\begin{tabular}{|c|c|c|c|c|c|c|c|}
\hline $\begin{array}{l}\text { Bore Hole Number } \\
\text { and Depth (1) }\end{array}$ & $\begin{array}{l}\text { Orientation } \\
\text { Relative to the } \\
\text { Bedding } \\
\text { Plane } \\
\text { (deg) }\end{array}$ & $\begin{array}{c}\text { Bulk } \\
\text { Density } \\
\left(\mathrm{g} / \mathrm{cm}^{3}\right)\end{array}$ & $\begin{array}{l}\text { Porosity } \\
(\%)\end{array}$ & $\begin{array}{c}\text { Real } \\
\text { Density } \\
\left(\mathrm{g} / \mathrm{cm}^{3}\right)\end{array}$ & $\begin{array}{c}\text { Surface } \\
\text { Area } \\
\left(\mathrm{m}^{2} / \mathrm{g}\right)\end{array}$ & $\begin{array}{c}\text { Average Pore } \\
\text { Diameter } \\
(\mu \mathrm{m})\end{array}$ & $\begin{array}{l}\text { Percent Porosity } \\
\text { Less Than } \\
10 \mu \mathrm{m}\end{array}$ \\
\hline & & $2.660^{(2)}$ & & & & & \\
\hline $8-92$ & $\sim 45$ & 2.685 & 2.023 & 2.741 & 0.444 & 3.91 & 91.4 \\
\hline \multirow[t]{2}{*}{$\begin{array}{c}8-92 \\
\text { (heated) }\end{array}$} & & 2.638 & 2.840 & 2.715 & 0.573 & 1.58 & 97.7 \\
\hline & & $2.602^{(2)}$ & & & & & \\
\hline $8-99$ & $\sim 45$ & 2.703 & 1.573 & 2.746 & b.332 & 0.89 & 78.5 \\
\hline \multirow[t]{2}{*}{$\begin{array}{c}8-99 \\
\text { (heated) }\end{array}$} & & 2.708 & 1.335 & 2.745 & 0.406 & 5.16 & 87.1 \\
\hline & & $2.674(2)$ & & & & & \\
\hline \multirow[t]{2}{*}{$13-88$} & $\sim 40$ & 2.717 & 1.025 & 2.745 & 0.241 & 4.00 & 88.9 \\
\hline & & $2.667^{(2)}$ & & & & & \\
\hline $18-119$ & $\sim 30$ & 2.697 & 1.511 & 2.738 & 0.405 & 3.82 & 89.9 \\
\hline \multirow[t]{2}{*}{$\begin{array}{c}18-119 \\
\text { (heated) }\end{array}$} & $\sim 30$ & 2.705 & 1.013 & 2.733 & 0.328 & 1.66 & 96.6 \\
\hline & & $2.709^{(2)}$ & & & & & \\
\hline $15-34$ & $\sim 30$ & 2.718 & 0.377 & 2.728 & 0.061 & 8.45 & 746 \\
\hline $\begin{array}{l}15-34 \\
\text { (heated) }\end{array}$ & & 2.714 & 0.414 & 2.725 & 0.083 & 7.55 & 77.4 \\
\hline
\end{tabular}

(1) The depth is reported in feet $(0.305 \mathrm{~m})$.

(2) Measured from thermal conductivity specimens before testing.

variations $\left(2.60\right.$ to $\left.2.71 \mathrm{~g} / \mathrm{cm}^{3}\right)$. Porosities varied from 1.0 to $3.0 \%$, except for Core 15-34 which gave $0.38 \%$. Real densities, which negate the porosity present in the malerials, were quite uniform. Orientation of the major axis of the cores varied between 30 and 45 degrees relative to the bedding plane for the group. These orientations will tend to average results on thermal-conductivity and expansion tests due to the anisotropy from layering. A relationship between changes in total porosity and heating to $673 \mathrm{~K}$ for four hours cannot be deduced, although porosity less than ten micrometers was observed to increase 3 to $8 \%$ on the specimens because of the heat treatment.

\section{THERMAL PROPERTIES}

\section{Thermal-Behavior Tests}

Differential thermal analyses-thermogravimetric analyses (DTA-TGA), using the Mettler Model TA-1 instrument, were conducted on portions of as-received cores at temperatures ranging from 298-673 $\mathrm{K}$ to determine the weight loss and any unusual calorimetric behavior of the materials. Representative powdered material was tested in air by using a heating rate of $6 \mathrm{~K} / \mathrm{min}$ in platinum crucibles. Temperature was monitered by using 
platinum/platinum-10\% rhodium thermocouples. Aluminum oxide (alumina) was the reference material.

Differential-scanning-calorimeter (DSC) measurements, using the Perkin-Elmer Model DSC-2 instrument, were also made over this temperature range to determine the amount of energy required to heat the materials as a function of the first and second temperature test cycles. Tests were conducted on nominally 100-milligram specimens in gold pans by using a heating rate of $10 \mathrm{~K} / \mathrm{min}$ in argon.

DTA-TGA and DSC measurements (reported in Table 2), indicated that the materials were relatively stable to $473 \mathrm{~K}$, although weight losses were observed on heating. No phase

Table 2

PERCENT WEIGHT LOSS OF POWDERED SHALE CORES

\begin{tabular}{llllll}
\hline & \multicolumn{5}{c}{ Core Number } \\
\cline { 3 - 6 } & $8-92$ & $8-99$ & $13-88$ & $18-119$ & $15-34$ \\
\hline From DTA-TGA Analysis $(298-673 \mathrm{~K})$ & & & & & \\
$\quad$ On Evacuation & 0.7 & 0.6 & 0.8 & 0.9 & \\
$\quad$ On Heating & 0.6 & 0.5 & 0.5 & 0.6 & \\
Total Loss & 1.3 & 1.1 & 1.3 & 1.5 & Not Tested \\
From DSC Analysis & & & & & \\
$\quad$ On Heating & 1.07 & 1.33 & 1.13 & 2.04 & No Change \\
\hline
\end{tabular}

changes were evident. On first heating, weight losses of between 1 and $2 \%$ were obtained. In the DTA-TGA apparatus, half the weight loss was during evacuation prior to heating This luss is attributed to the release of absorbed rather than bound watcr. Core 15-34 showed no weight loss.

Very small changes of one percent or less in heating-energy requirements by DSC were observed for the second heating cycle relative to the first. DTA-TGA measurements were not performed on Core 15-34 because stable behavior was noted from the DSC measurements.

Scanning electron microscope (SEM) photomicrographs of two sections taken from Core 8-92 (one as received and the other heated to $673 \mathrm{~K}$ for four hours) are included (Figures 6 and 7). Few differences are observed in the two sets of photomicrographs. At 300 to $1000 \mathrm{X}$, slight deagglomeration or breaking up of occluded particles may be indicated.

\section{Heat-Capacity Measurements}

A Perkin-Elmer differential scanning calorimeter (DSC-2) was used to determine the heat capacity of the core material from 298 to $673 \mathrm{~K}$. Representative material from 


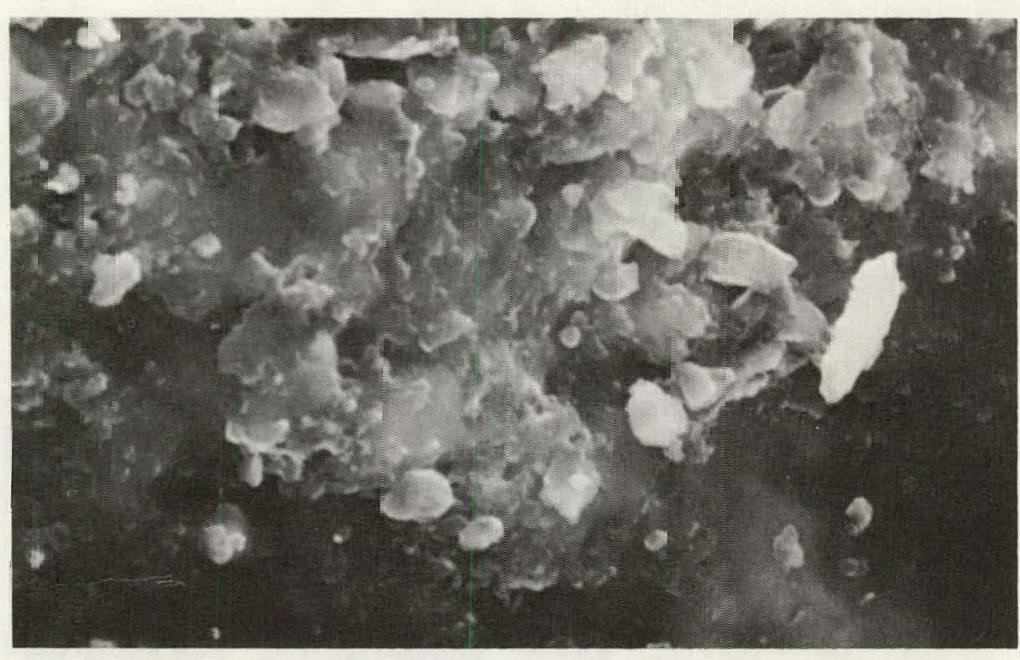

(E) f.t $3000 \mathrm{x}$.

SM-66296

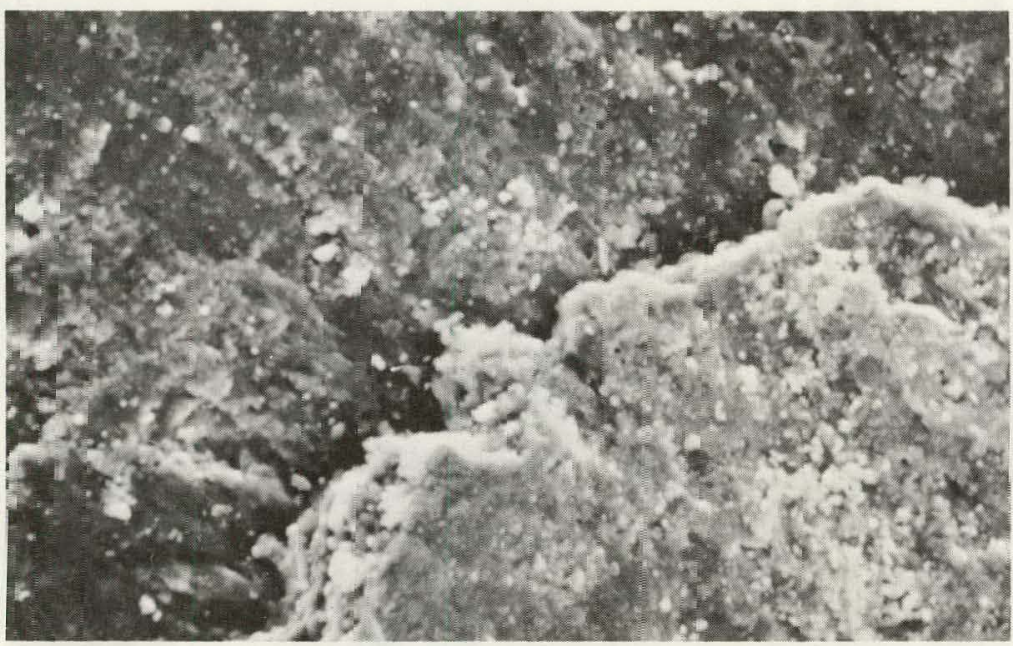

(c) At $300 \mathrm{X}$

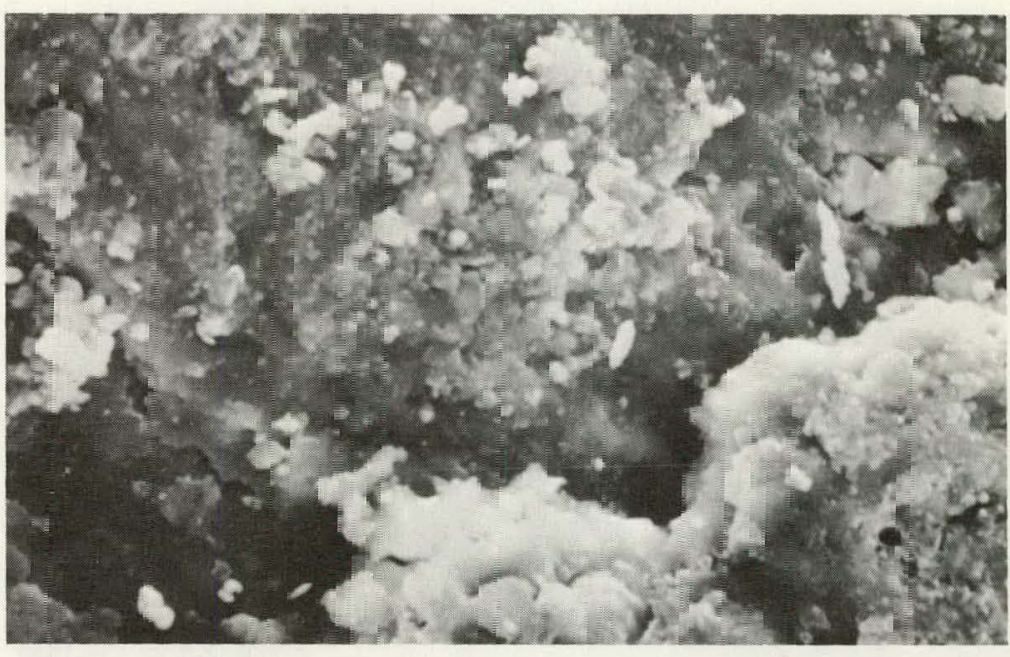

(b) At $1009 \mathrm{X}$

SM-66297

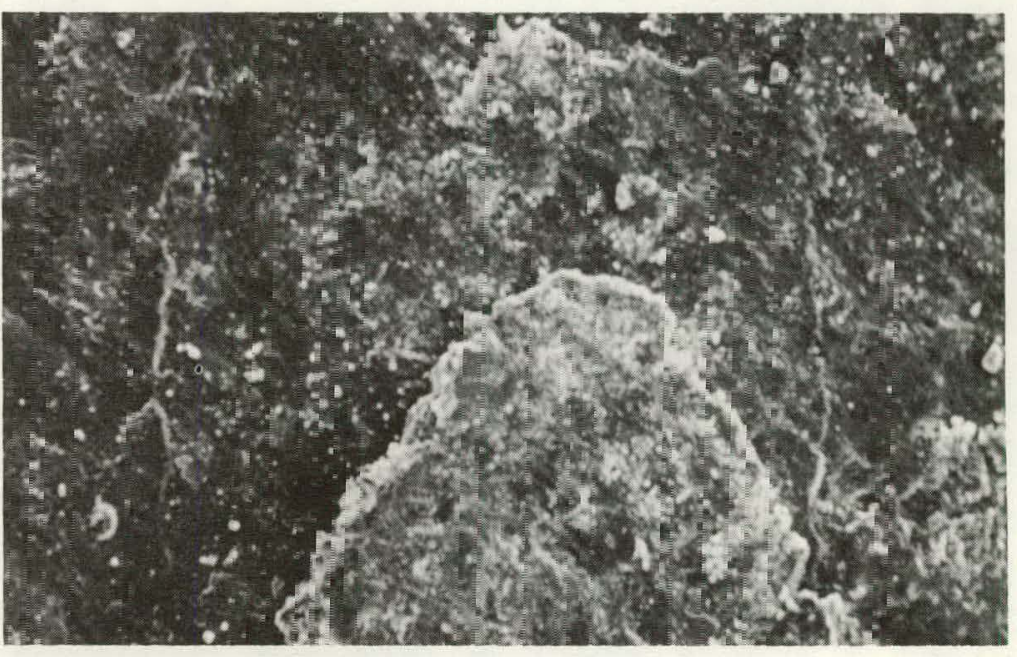

(d) A.t 1CJX.

SM-66300

Figure 6. PHOTOMICROGRAPHS OF AS-RECEIVED SHALE AT CIFFERENT N F.G VI=ICATIONS. ICore \&-92) 

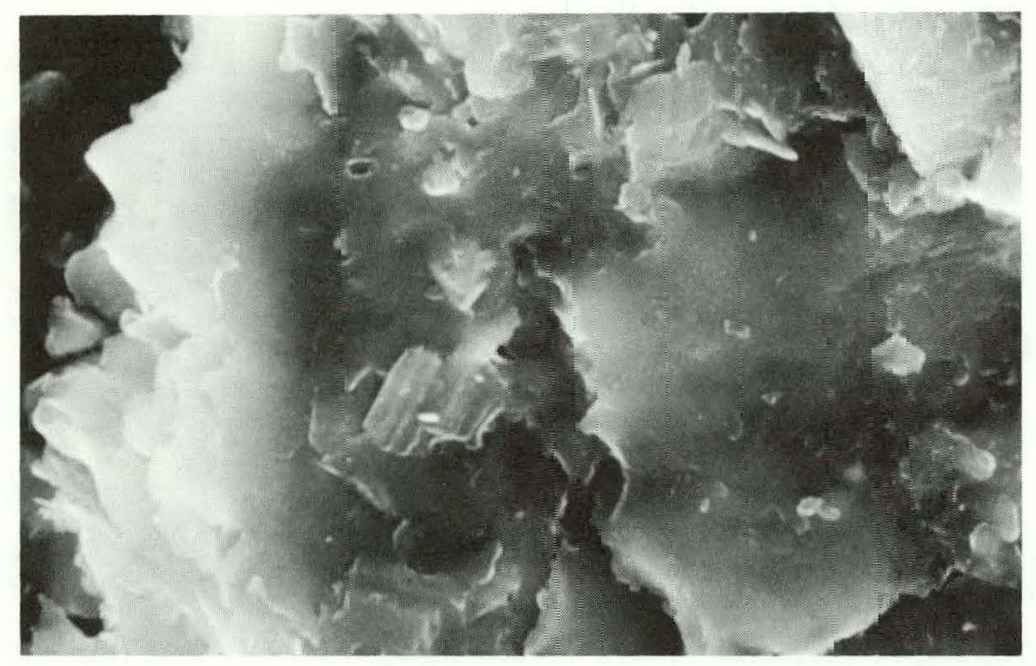

(a) At 3000X.

SIM-66301

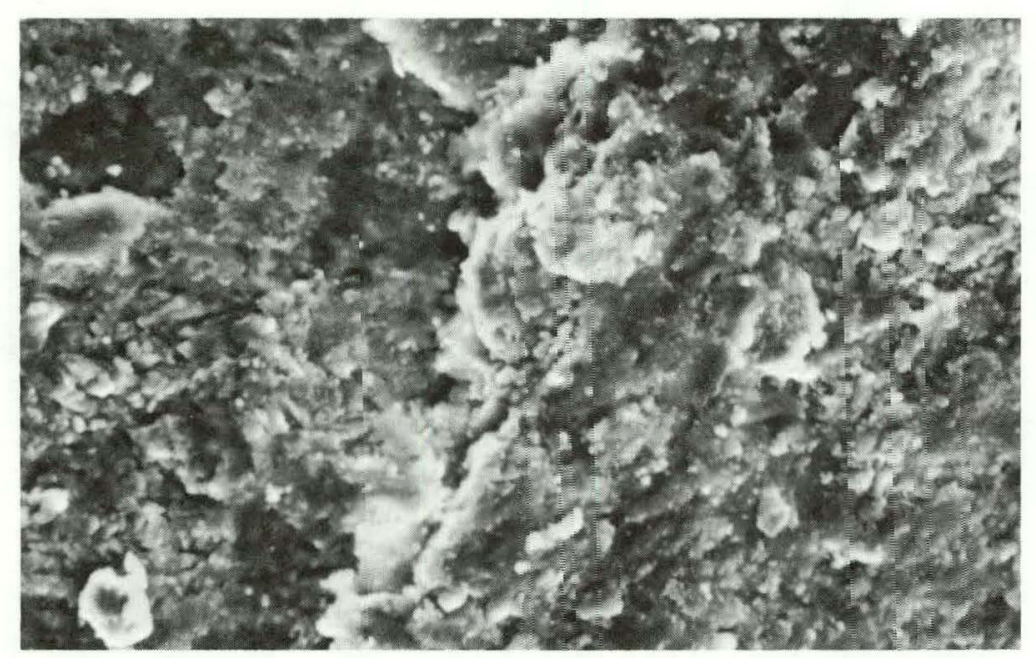

(c) At 300x.

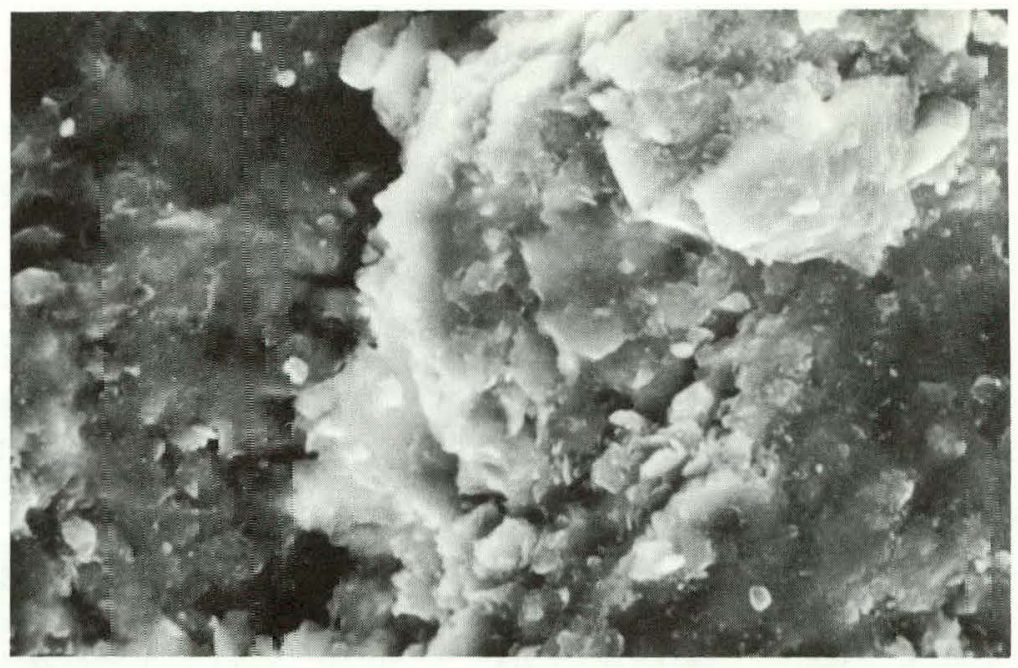

(b) At 1000x.

SM-66302

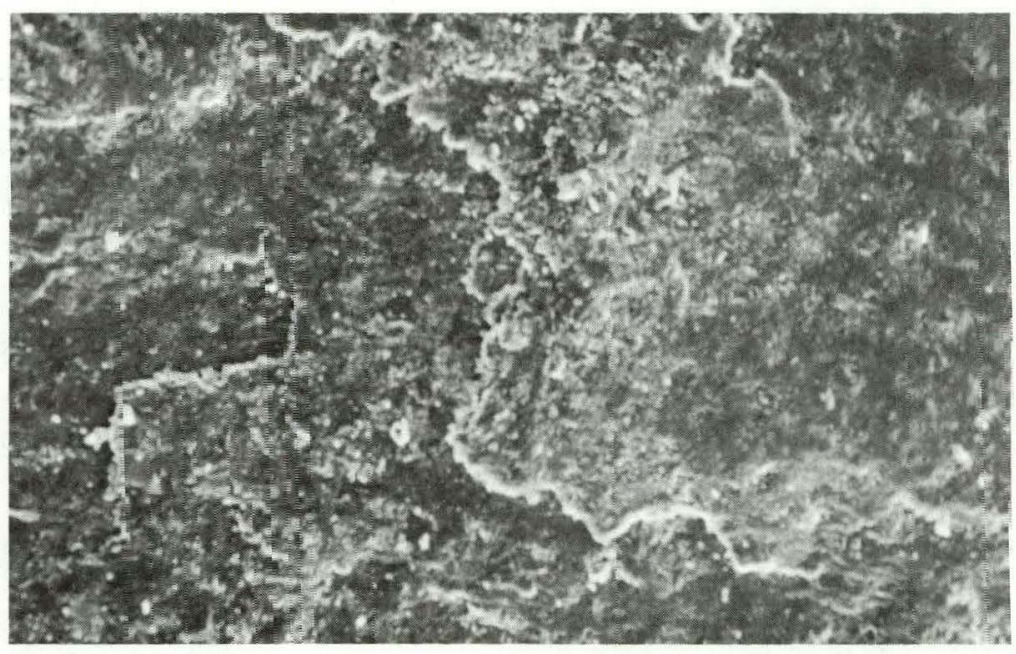

(d) At $100 \mathrm{XX}$.

SM-66304

Figure 7. PHOTCIMICROGRAPHS OF HEAT-TREATED SHALE AT DIFFERENT MAGNIFICATIONS. (Core 8-92) 
each core was finely. powdered in an agate mortar and pestle and sealed in aluminum sample pans.

This instrument determines the energy required to maintain equal temperatures of sample and reference stages at constant heating or cooling rates. The energy required to heat a known mass of standard material ( $\alpha$-alumina) is directly related to that for a known mass of shale under the same test conditions. Energy requirements, represented as differential amplitudes, were determined by using a heating rate of $10 \mathrm{~K} / \mathrm{min}$ over temperature intervals of $20 \mathrm{~K}$. Data were taken at $50-\mathrm{K}$ temperature increments over the temperature range. Experimental data were fitted to an equation of the form:

$$
c_{p} \equiv a+b T+c T^{-2}
$$

where:

$$
\begin{array}{ll}
\mathrm{C}_{\mathrm{p}} & \text { represents the heat capacity (in cal } / \mathrm{g}-\mathrm{K} \text { ), and } \\
\mathrm{T} & \text { the temperature (in } \mathrm{K} \text { ). }
\end{array}
$$

$a, b$, and $c$ are constants.

Calculations and plots were made by using a PDP-15 computer. 2,3 Measurement error is estimated at $\pm 1.5 \%$ of the stated values for stable materials.

Heat-capacity measurements by DSC (Figure 8 ) indicate that three of the cores (Cores 8-92, 8-99, and 18-119) gave practically identical results within the limits of experimental error (ranging from $0.21 \mathrm{cal} / \mathrm{g}-\mathrm{K}$ at $293 \mathrm{~K}$ to $0.28 \mathrm{cal} / \mathrm{g}-\mathrm{K}$ at $673 \mathrm{~K}$ ). These values are reasonably similiar to those of alumina, the standard which was used in the test. Cores 13-88 and 15-34 gave lower values which indicate compositional variations. Small positive deviations in the heat-capacity values around $373 \mathrm{~K}$ are considered to be due to absorbed water which is subsequently evolved at higher temperatures.

\section{Thermal-Expansion Measurements}

Thermal linear expansions were determined from 293 to $673 \mathrm{~K}$, using a Dynatech-Netysch Model $402 \mathrm{E}$ automatic quartz pushrod dilatometer. Tests were conducted with a programmed heating rate of $2 \mathrm{~K} / \mathrm{min}$ in helium.

Test data [temperatures from an iron/constantan thermocouple and displacements from a linear variable differential transformer (LVDT)] were multiplexed and digitally recorded on paper tape for computerized data reduction. ${ }^{4}$ A National Bureau of Standards borosilicate glass standard (SRM 731) was used to correct the system for the expansion of the quartz cradle and associated temperature gradients in the measurement zone. Some duplicate specimens and second tests (reruns) were also conducted to assess the variability in expansion values and the effects of heating the materials on subsequent expansion tests. Measurement error is estimated at $\pm 1.2 \%$ of the values recorded at the upper temperature limit $(673 \mathrm{~K})$. 


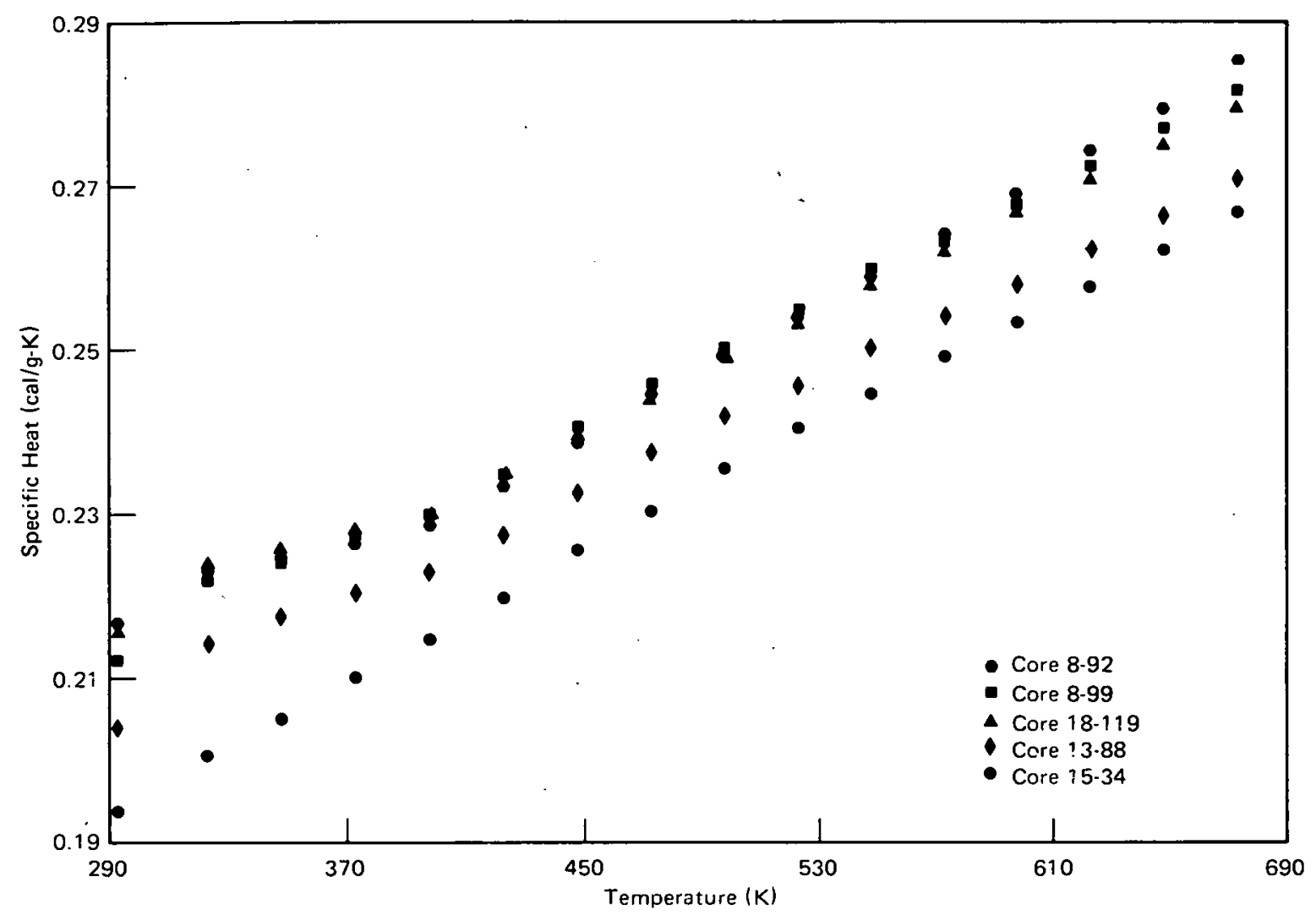

Figure 8. SPECIFIC-HEAT VALUES FOR THE FIVE CORES.

Representative thermal-expansion data are reported in Figures 9 - 12. Core 13-88 was not tested because appropriate expansion specimens could nnt he fahricated. Linear-thermal expansion values varied considerably in both the longitudinal and transverse direction relative to the vertical axis of the cores. Expansion for the group varied between 0.2 and $0.5 \%$ at $673 \mathrm{~K}$ relative to $298 \mathrm{~K}$. A sixth-order equation was used to fit the data because of the occurrence of regions of localized swelling and contractions, especially with Cores 8-92, 8-99, and $18-119$ in the temperature range from 360 to $500 \mathrm{~K}$. Only Core 15-34 gave smooth expansion data without this cyclic expansion behavior, possibly because of the limestone present. The expansion averaged $0.5 \%$ over the temperature range. Second heating cycles minimized the swelling/shrinking behavior which was most evident in the longitudinal-core orientations. Net expansion was usually higher on the second versus the first temperature cycle, possibly because of the net contraction (shrinkage) in the test length due to the first heating cycle.

No general trends of expansive behavior versus orientation can be derived from these data. Expansion is apparently unique to each specimen and related to variations in structure, fine cracks and fissures, and texturing. All specimens were observed to be intact on posttest examination. 


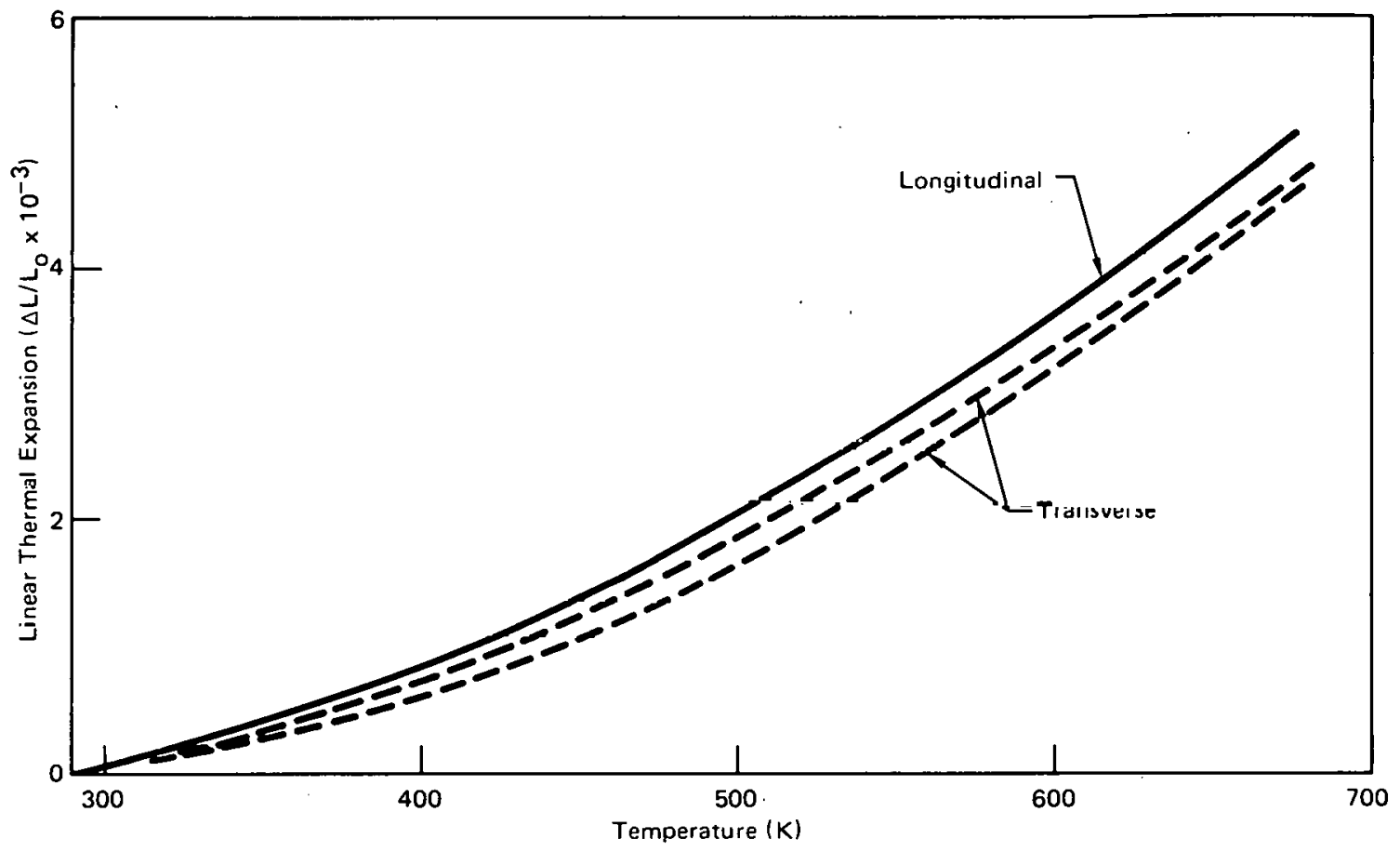

Figure 8. EXPANSIVF, REHAVIOR OF CORE 15-34.

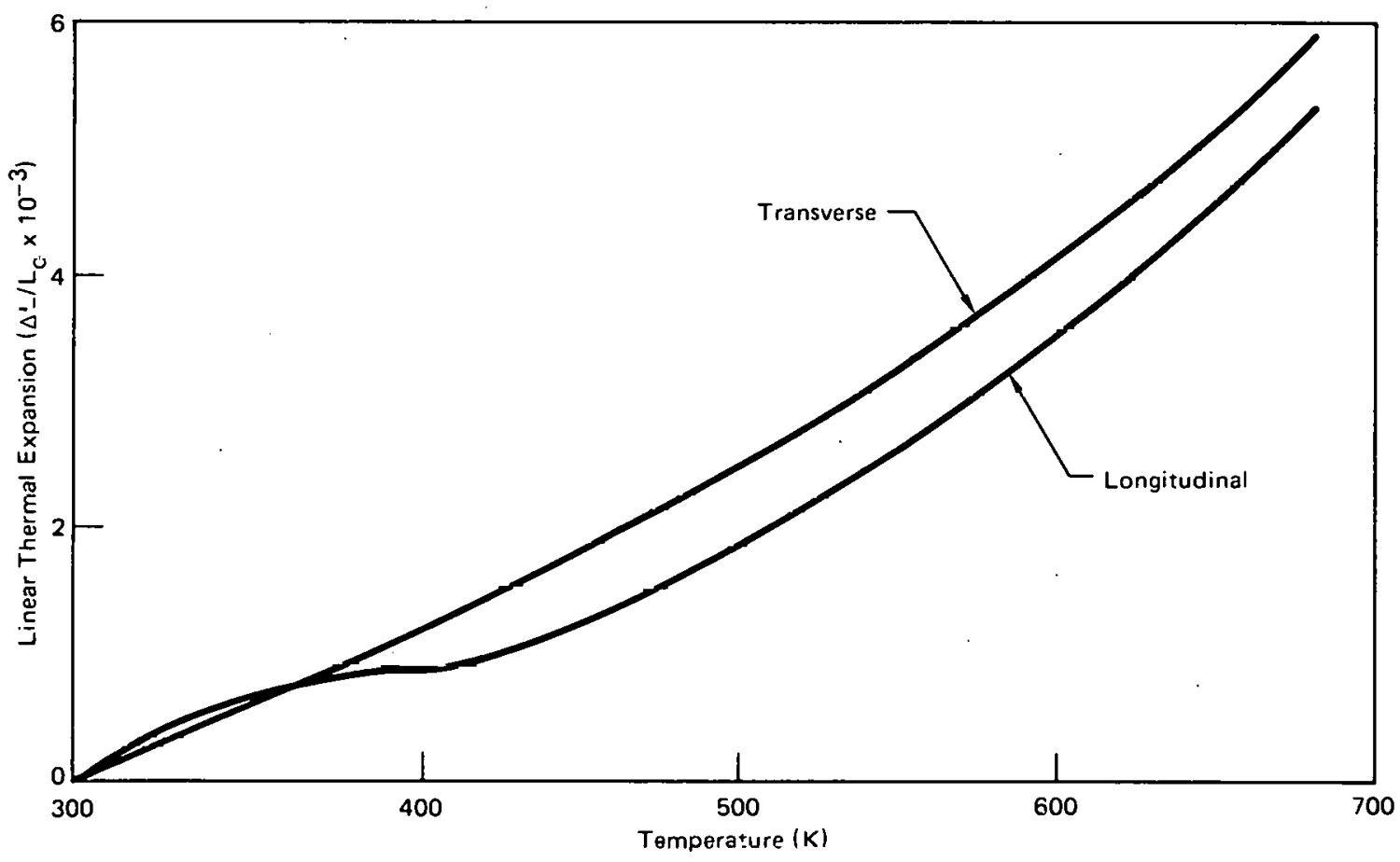

rigure 10. EXPANSIVE BEHAVIOR OF CORE 8-99. 


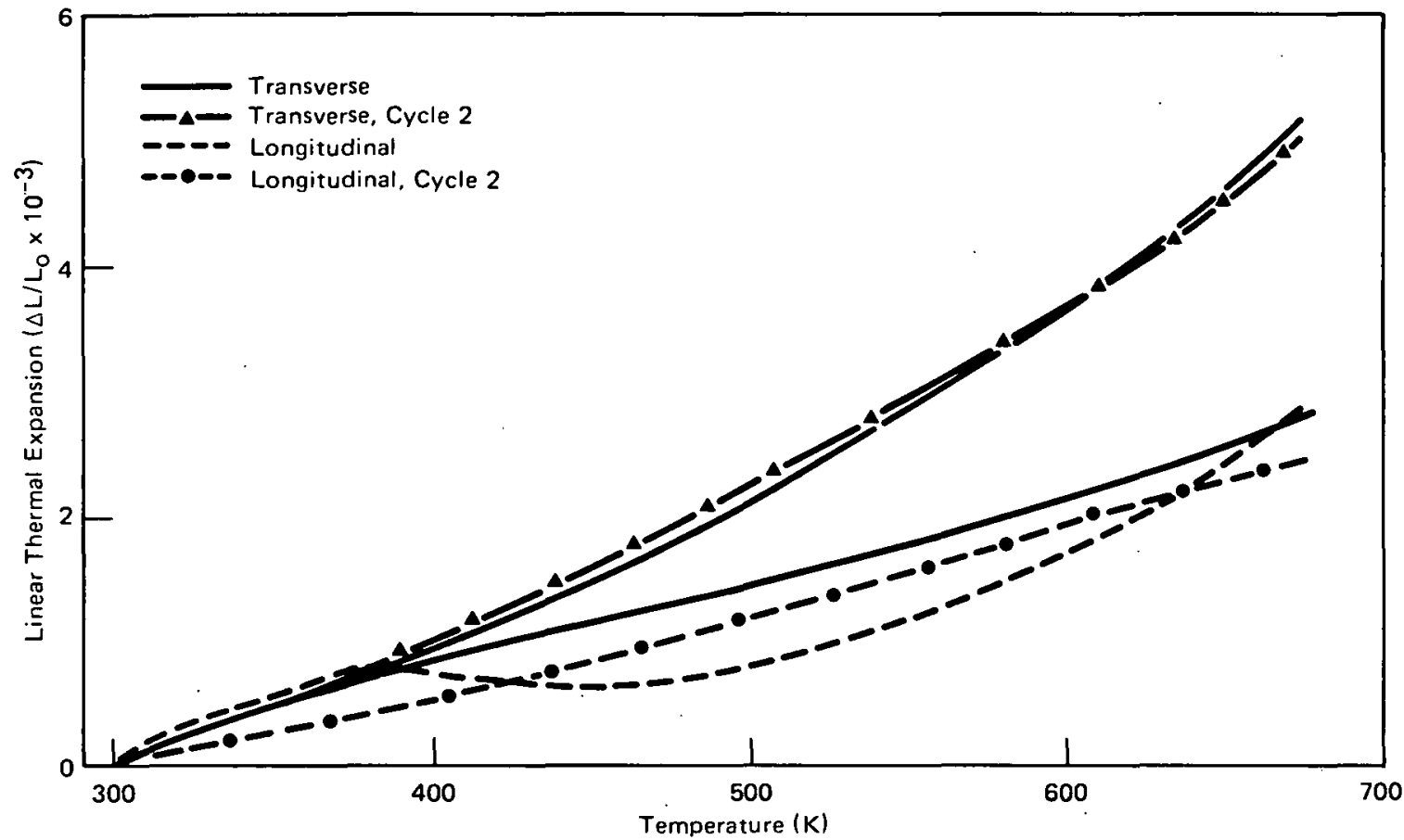

Figure 11. EXPANSIVE BEHAVIOR OF CORE 8-92.

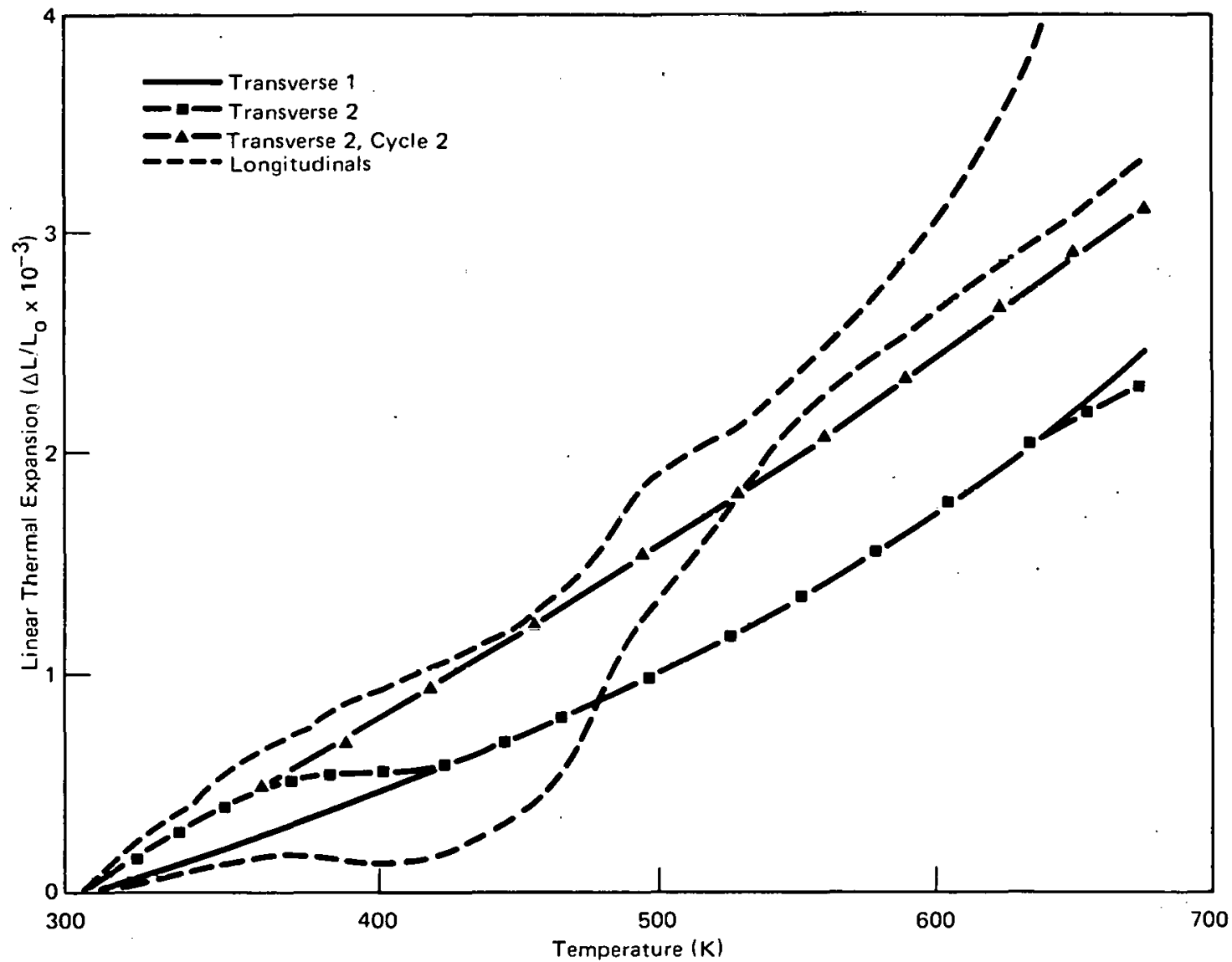

Figure 12. EXPANSIVE BEHAVIOR OF CORE 18-119. 


\section{Thermal-Conductivity Measurements}

Thermal-conductivity measurements were made by using two different instruments. A thermal comparator was used for the room-temperature screening measurements. A guarded, steady-state, unidirectional-heat-flow instrument was used in measuring thermal conductivities at elevated temperatures.

Purdue Thermal Comparator - The thermal comparator was assessed for its applicability for thermal-conductivity screening measurements because it can make determinations very quickly. It was also used to determine the appropriate standards to be used with the shale in the elevated-temperature tests. One major disadvantage with this test is that specimen surface preparation must be identical to that of the standards. The same set of specimens was used in both the room-temperature-comparative and elevated-temperature tests.

A thermal comparator instrument, developed at Purdue's Thermophysical Properties Research Center (TPRC), the TPRC Thermal Comparator Model 100, was used in these screening measurements. While this technique ${ }^{5}$ has been evaluated for such applications as metal sorting and case hardening, limited investigations have been made on such heterogeneous materials as rocks. Lórentzen ${ }^{6}$ used the technique for evaluating the thermal conductivity of natural stones having thermal conductivities in the range from 2.0 to 8.9 W/m-K.

The thermal comparator determines the difference in temperature between a very small hemispherical, heated probe and the surface of a specimen. The probe geometry is given in Figure 13. The probe was operated with a temperature differential 20 degrees above ambient temperature. A lever actuates the probe which very lightly touches the surface of the sample at room temperature. The loss of heat from the probe to the sample is determined by a differential thermocouple with one junction embedded at the tip and the other in the much larger body of the probe, which acts as partially infinite heat source. The differential signal is conditioned, amplified, and read out on a digital voltmeter. The initial few seconds after contact give a transient-temperature-loss situation which quickly stabilizes to a linear-heat-loss curidition. In these tests, the output was recorded ten seconds after initial contact. The specimen thermal conductivity is expressed by the equation:

$$
K_{2}=\frac{T_{1}-T_{C}}{T_{1}-T_{2}}\left(K_{1}+K_{2}\right)
$$

where:

$T_{C}$ represents the intermediate probe temperature after sample contact,

$T_{1}$ the initial probe temperature,

$T_{2}$ the specimen temperature,

$K_{1}$ the thermal conductivity of the probe, and

$\mathrm{K}_{2}$ the thermal condus.tivity of the specimen. 

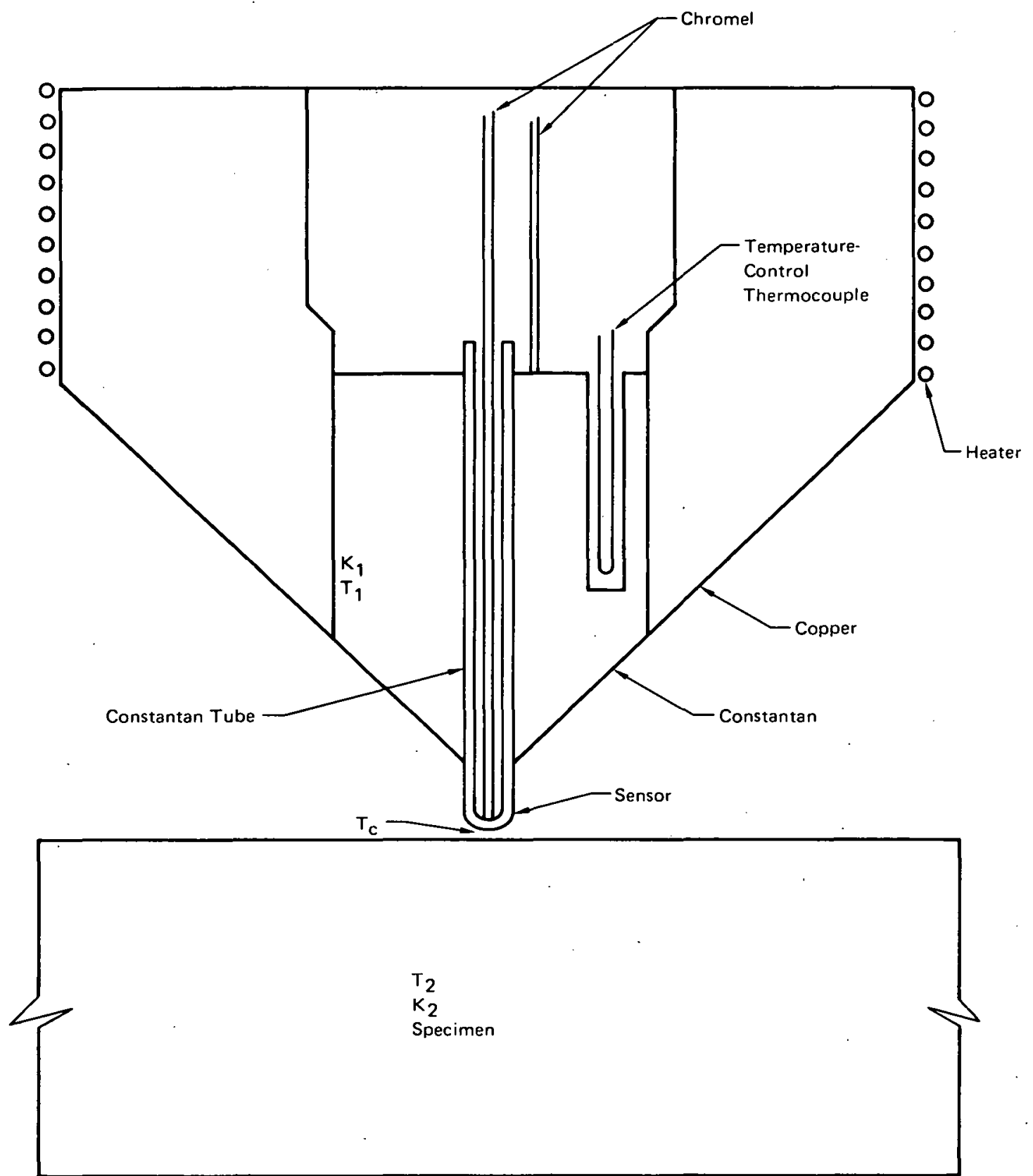

Figure 13. DETAILS OF THE THEFMOPHYSICAL PROPERTIES RESEARCH CENTER'S THERMAL COMPARATOR MODEL 100 PROBE DESIGN.

A typical response of the probe to different-thermal-conductivity materials is indicated in Figure 14. By bracketing the output of the unknown conductivity material with standards of dimensions and surface finishes equivalent to those of the unknown, values can be rapidly obtained. For inhomogeneous materials such as shale, many test locations on the surfaces of the specimens were sampled. Tests were conducted in a constant-temperature room $( \pm 0.5$ $\mathrm{K}$ ), using a large aluminum plate as a heat sink for maintaining an initial constant temperature of the specimens and standards before and after testing. Cotton gloves were 
used in handling the specimens to prevent contamination of the sample surfaces and to minimize changing the temperature of the specimen with body heat.

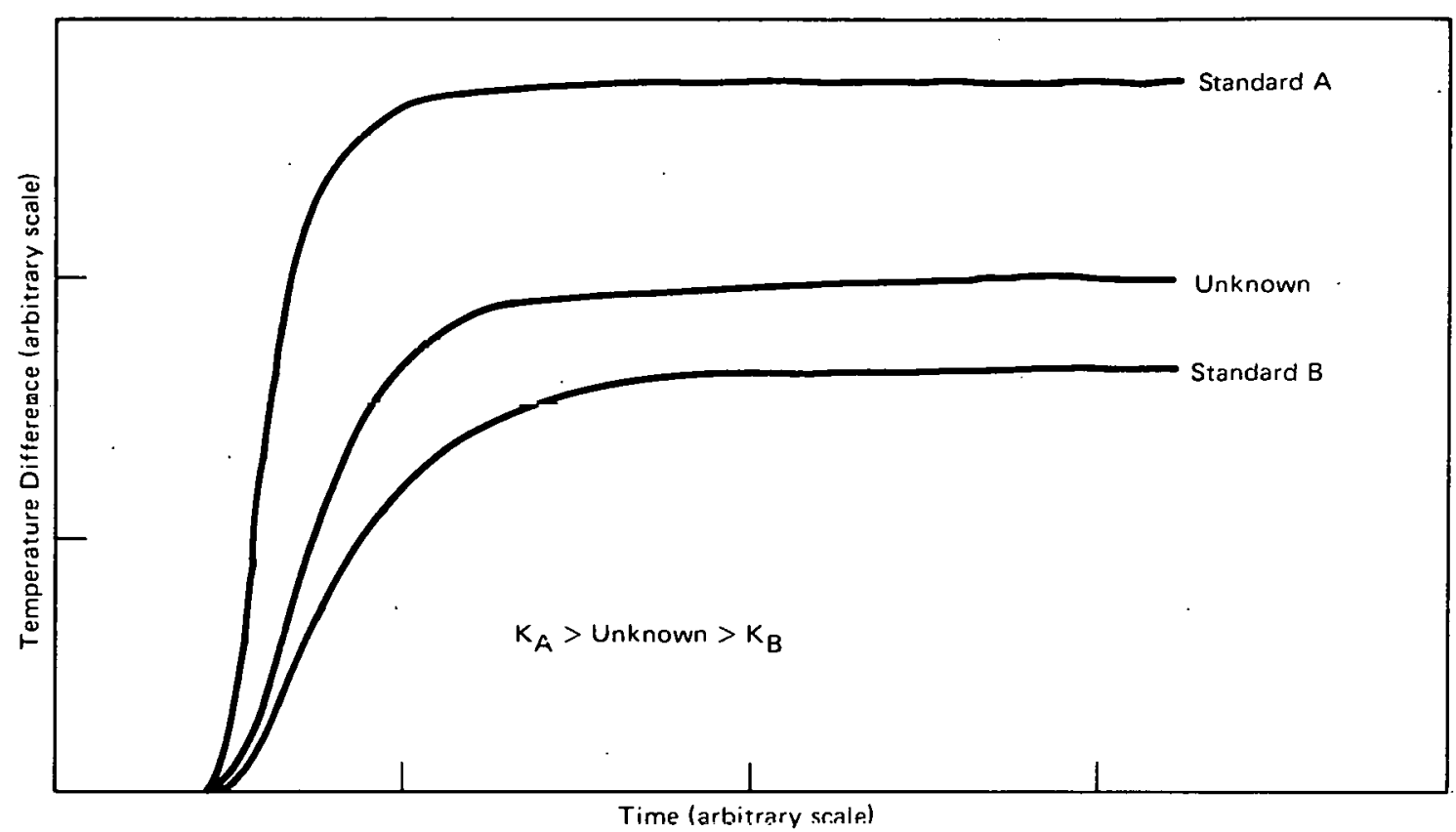

Figure 14. TYPICAL RESPONSE FROM THE THERMAL COMPARATOR TO MATERIALS HAVING SIMILAR CONDUCTIVITIES, DIMENSIONS, AND SURFACE FINISHES.

Thermal-conductivity measurements on the shale cores are plotted in Figures 15 and 16. TPRC thermal comparator data $(298 \mathrm{~K})$ were obtained by averaging 30 individual test locations on each shale surface. Standards of titanium alloy, quartz, and glass were used as bracketing references. Although surface finishes of the cores were not as good as those on the standards, due to the heterogeneous nature of the material, relative agreement with data taken from the Dynatech comparative apparatus was observed.

Thcrmal-Conductivity Measurements at Elevated Temperatures - Thermal-conductivity measurements at elevated temperatures were made on the core specimens by using the Dynatech Model TCFCM-20 apparatus. This test is based on steady-state, unidirectional heat flow where the specimen is sandwiched between standards of known conductivity. A temperature gradient of about 50 degrees $K$ is established through the test configuration by using a main and auxiliary heater (Figure 17). A guarding furnace, which has two separate temperature control sections, is used to minimize radial heat losses or gains by matching the temperature profile of the guard with that through the test stack. Santocel insulation fills the annular cavity between the test stack and guarding furriace.

With steady-state conditions, assuming no heat losses or gains such as guarding furnace mismatch or surface contact losses, a constant and uniform heat flux is impressed on the standards and sample. The heat flowing through the standards and samples is a constant. From the integrated form of Fourier's law: 


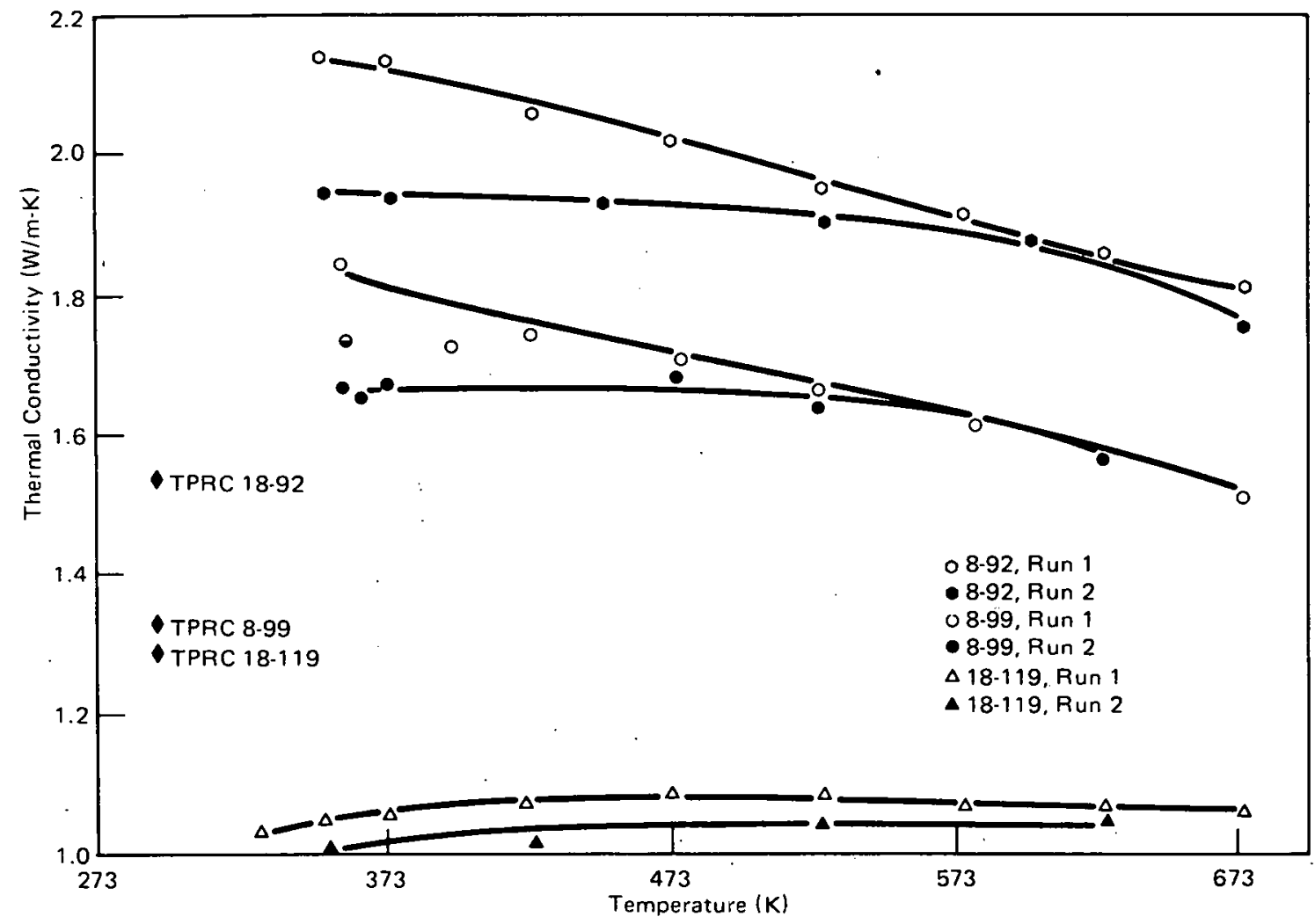

Figure 15. THERMAL-CONDUCTIVITY DATA OF SHALE CORES. (Cores 8-92, 8-99, 18-92, and 18-119)

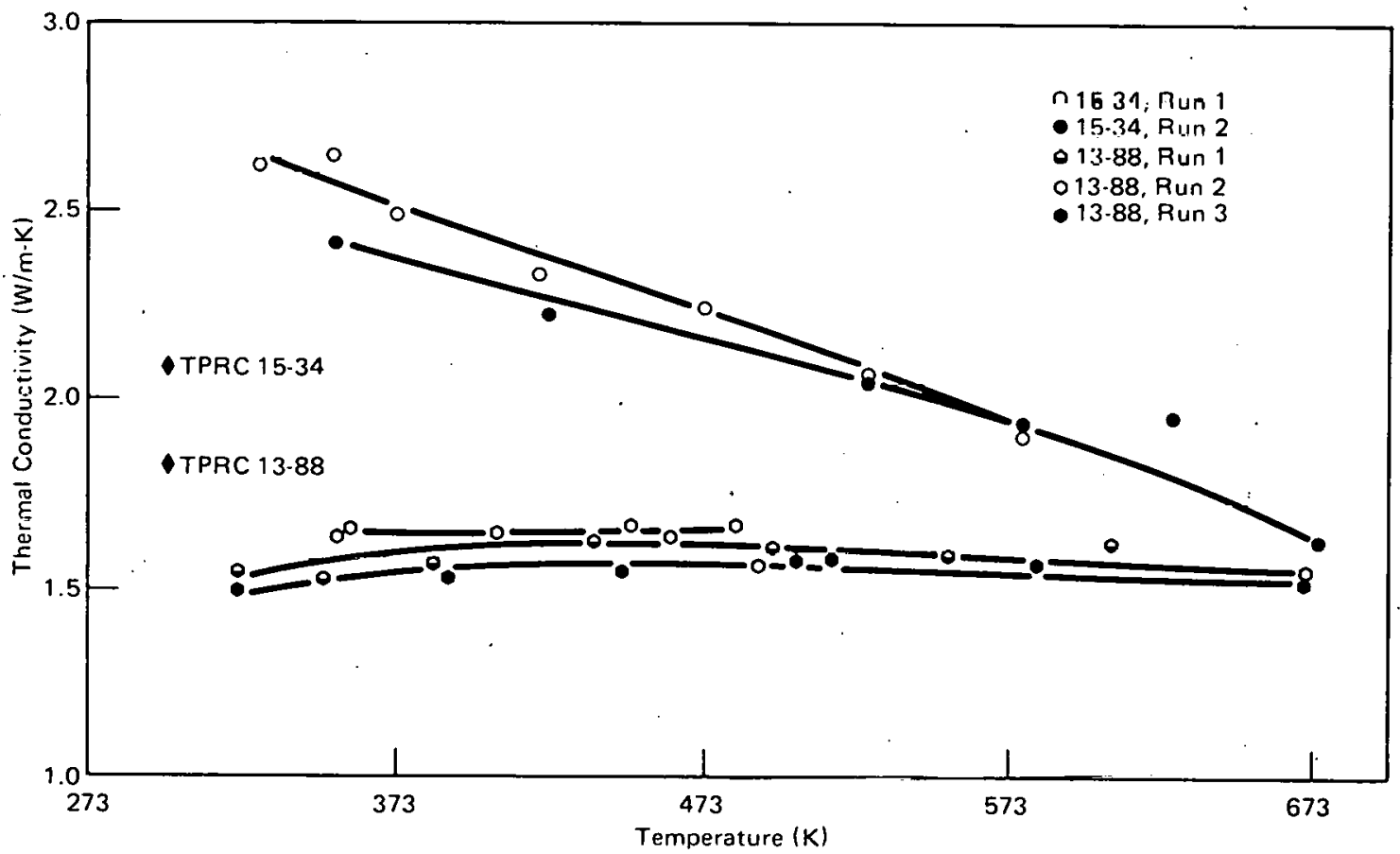

Figure 16. THERMAL-CONDUCTIVITY DATA OF SHALE CORES. (Cores $15-34$ and 13-88) 


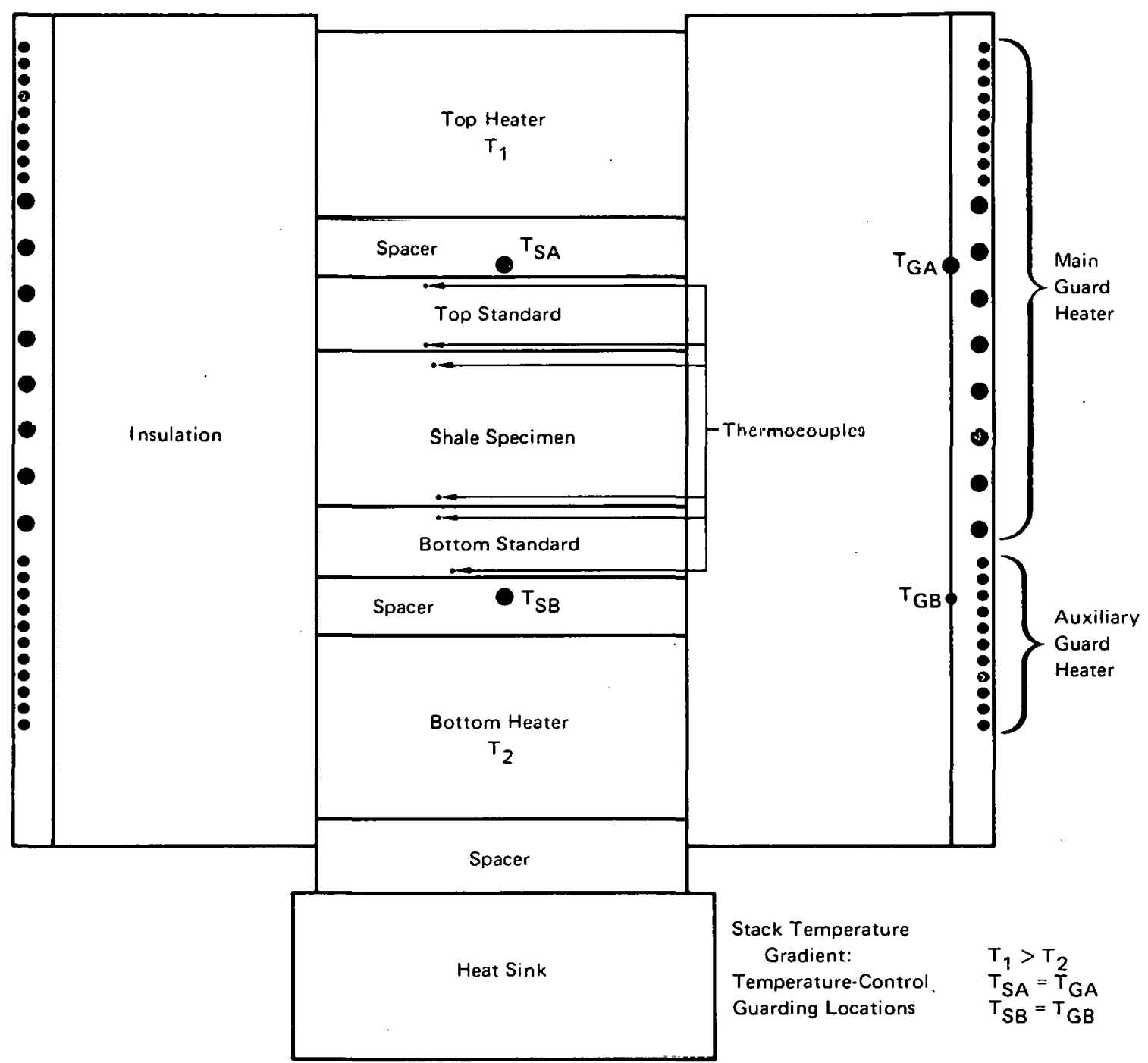

Figure 17. CONFIGURATION OF THE DYNATECH TCFCM N-20 THERMAL-CONDUCTIVITY APPARATUS. (Stack Assembly and Guarding Furnace)

$$
Q=-K A\left(\frac{\Delta T}{\Delta X}\right),
$$

where:
$K$ represents the thermal conductivity,
A the cross-sectional area normal to the heat flow,
$\Delta T$ the temperature difference betwcen two points, and
$\Delta \mathrm{X}$ the distance between two points.

it is possible to calculate $K$, if the heat flowing through the standard, Qs, is identical to that flowing through the specimen, Ox. Equation 3 can be writter: 


$$
\text { sample } K=\frac{\text { A standard }}{A \text { sample }} \frac{\Delta T \text { standard }}{\Delta T \text { sample }} \frac{\Delta X \text { sample }}{\Delta X \text { standard }} K \text { standard, }
$$

and the ratio of the thermal conductivity of the specimen to the standard can be calculated if the cross-sectional areas, thicknesses, and temperature differences of the sample and standard are known. The thermal conductivity of the standard is usually taken at its average temperature rather than that of the test sample. This approach vields two calculations, one with the standard at a higher average temperature relative to the test sample and one with a standard at an average temperature lower than the test sample.

Pyrex 7740 glass was used as the standard in the shale tests. Diameters and thicknesses of Pyrex and shale specimens were measured by using micrometers. Type K, B and S 30 gauge, Chromel-Alumel thermocouples were bonded into slots in the surfaces with Astroceram furnace cement for the glass and a mixture of ground shale and sodium silicate for the shale (Figure 17). A correction for the thickness of the individual thermocouple beads was applied to the gross-thickness measurements for each test. Variations in the surfaces of the shales caused high thermal.contact resistance in an "as-stacked" state. To minimize this contact resistance, a thin film of high-conductivity heat-transfer paint (Silver Print) was used to bond the surfaces of the glass and the shales together. Nickel spacers were used to conduct heat from the heaters to the test stack.

In testing, the stack was assembled and the conductive paint was allowed to dry overnight. The system was then purged with dry nitrogen and the assembly heated to the desired temperatures. Approximately a two-hour equilibration time was observed before thermocouple emfs were recorded. Data were taken at 50-degree increments up to $673 \mathrm{~K}$. The system was then allowed to cool and the testing sequence repeated to determine the effects the first cycle had on subsequent thermal-conductivity values.

Thermal-conductivity measurements obtained with the Dynatech comparative instrument are listed in Table 3. The instrument was calibrated by testing Pyrex standards with a Pyroceram 7740 sample over the temperature range. Results indicated that, for ten separate measurements, all were within $\pm 3.4 \%$ of the recommended values. Average error for the ten measurements was $2.60 \%$. (The manufacturer.'s stated precision is $\pm 5 \%$.)

Thermal-conductivity data for the shale varied by a factor of three, ranging from 1.0 to 2.8 $\mathrm{W} / \mathrm{m}-\mathrm{K}$. There is a general trend of decreasing conductivity values with increasing temperature for three of the five specimens. Cores $18-119$ and $13-88$ yielded values that were constant over the temperature range. Second tests showed a reduction of the conductivity values between 1 and $10 \%$ at lower temperatures. Thermal-conductivity data obtained from these tests are in the same order of magnitude as those from published values, ${ }^{7}$ which are 1.7 to $1.0 \mathrm{~W} / \mathrm{m}-\mathrm{K}$. 
Table 3

THERMAL CONDUCTIVITY OF SHALE CORES WHEN USING PYREX 7740 STANDARDS

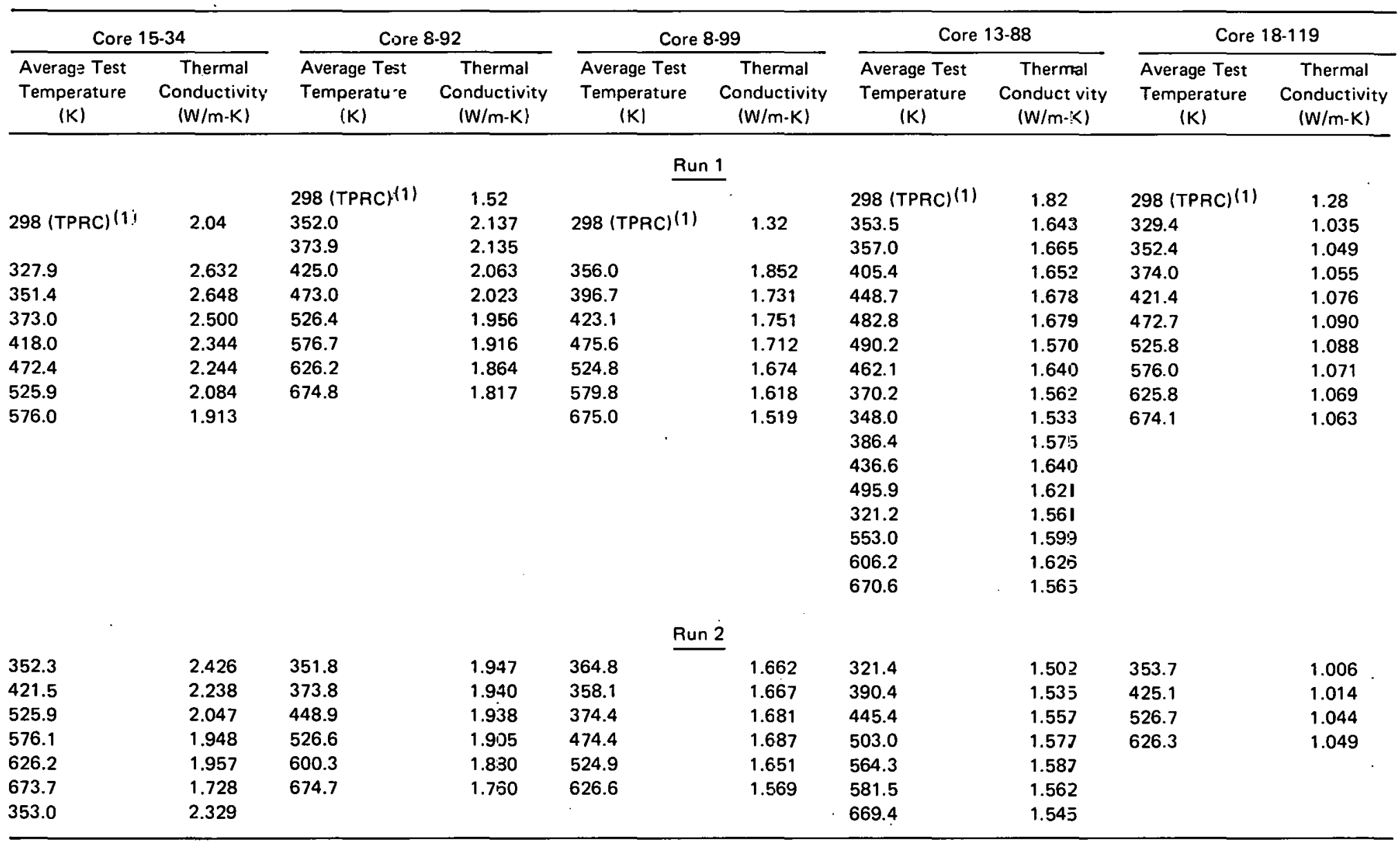

(1) TPRC - thermal comparator measurement. 


\section{CONCLUSIONS}

Physical and thermophysical property measurements on the representative shale cores indicated that a significant variation in properties exists in the shale bed of the In Situ Conasauga Experiment. This range of properties is clearly indicated by the results obtained from density, porosity, thermal-conductivity, and thermal-expansion tests. Thermal cycling changes the thermal and mechanical properties of the material, as evidenced by the thermal-conductivity and expansion tests.

Influence of the material history relative to water or moisture absorption and related heat treatments which drive off the nonchemically bound water also affect the data obtained from such tests. To adequately characterize such geological formations, a large number of tests are required to ensure that statistical and representative sampling is obtained for test measurements.

Fabrication techniques applicable to making test specimens from friable cores include using low-speed cutting devices, such as diamond-impregnated saws, wire saws, or cutoff wheels, to limit the shattering effects of mechanical vibrations. Standard machining techniques are not feasible because of the friability of the material. Smooth, polished surfaces can be obtained by using standard metallurgical techniques, or by hand.

The TPRC comparative probe is a quick, cost-effective, thermal-conductivity screening technique if surface preparation is consistent and appropriate geological standards of similiar nature can be obtained.

Recommended methods of reducing the cost of thermal-conductivity measurements depend primarily on reducing the cost of sample preparation. Rough-cut (unpolished) surfaces for thermal-conductivity specimens can be effectively bonded with high-conductivity, stable-heat-transfer coatings to minimize sample-preparation costs, as steady-state, comparative-technique test times are limited by the thermal inertia of a given test apparatus. 


\section{ACKNOWLEDGEMENTS}

The author wishes to thank members of the $Y-12$ Plant Laboratory for performing the DTA-TGA measurements and R. K. Bennett, Jr, for providing the scanning electron photomicrographs. 


\section{REFERENCES}

1. Dell'Amico J. J., et al; Characterization and Thermal Conductivities of Some Samples of Conasauga Shale, ORNL-MIT-20; March 1967.

2. Davenport, C. M.; Specific Heat Data Analysis, Internal Memorandum; March 21, 1976.

3. Davenport, C. M.; Instructions for Running the GENFIT and GENPLT Programs, Internal Memorandum; April 21, 1975.

4. Brunton, G. D., Office of Waste Isolation; Personnal Communication; September 1977.

5. Powell, R. W., and Clark, W. T.; "Measurement of Thermal Conduction by the Thermal Comparator", J Sci Instrumen, 39, pp 545 - 551 (1962).

6. Lorentzen, G.; "Measuring the Heat Conductivity of Natural Stones by the Thermal Comparator Method", Bull IntnI Inst Refrigeration, Ann 1966-2، pp 257 - 268 (1966).

7. Birch, F.; Handbook of Physical Constants; Geological Society of America (1942). 


\section{Distribution}

Department of Energy - Oak Ridge

Hickman, H. D.

Leed, R. E.

Zachry, D. S., Jr

Lawrence Livermore Laboratory

Nelson, W. E.

Los Alamos Scientific Laboratory

Hoyt, $H$ : C.

Oak Ridge Gaseous Diffusion Plant

Arendt, J.W.

Levin, R. W.

Stief, S. S.

Wilcox, W. J., Jr

Oak Ridge National Laboratory

Llewellyn, G. H.

McElroy, D. L.

Morgan, M. T.

Weir, J. R., Jr.

Zapp, F. C.

Oak Ridge Y.12 Plant

Armstrong, R. C.

Briscoe, O.W.

Burditt, R. B.

Burnett, A. W. (OWI)

Claiborne, H. C. (OWI)

Cuddy, L. M.

Dodson, W. H./Googin, J. M.

Duggan, H. G.

Fortenbery, M. J.

Fraser, R. J.

Jackson, V. C.

Keith, A.

Kite, H. T.

Mason, D. L.

McCaulcy, L. L. (OCPO)

McLendon, J. D.

Mills, J. M., Jr

Phillips, L. R.

Schneider, P. G.

Smith, D. D. (5)

In addition, this report is distributed in accordance with the Category UC-70, Nuclear Waste Management as given in the USERDA Standard Distribution Lists for Unclassified Scientific and Technical Reports, TID-450ก
Smith, R. D.

Tewes, W. E.

Thompson, W. H., Jr

$Y-12$ Central Files (master copy)

$Y-12$ Central Files (route copy)

$Y-12$ Central Files $(Y-12 R C)$

$Y-12$ Central Files (5)

Paducah Gaseous Diffusion Plant

Bewley, H. D.

Union Carbide Corporation - New York

Tinsley, S. W. 